\title{
UNIVERSITYOF BIRMINGHAM

\section{Isotopic signatures suggest important contributions from recycled gasoline, road dust and non-exhaust traffic sources for copper, zinc and lead in PM10 in London, United Kingdom}

Dong, Shuofei; Ochoa Gonzalez, Raquel; Harrison, Roy M.; Green, David; North, Robin; Fowler, Geoff; Weiss, Dominik

DOI:

10.1016/j.atmosenv.2017.06.020

License:

Creative Commons: Attribution-NonCommercial-NoDerivs (CC BY-NC-ND)

Document Version

Peer reviewed version

Citation for published version (Harvard):

Dong, S, Ochoa Gonzalez, R, Harrison, RM, Green, D, North, R, Fowler, G \& Weiss, D 2017, 'Isotopic

signatures suggest important contributions from recycled gasoline, road dust and non-exhaust traffic sources for copper, zinc and lead in PM 1 in London, United Kingdom', Atmospheric Environment, vol. 165, pp. 88-98. https://doi.org/10.1016/j.atmosenv.2017.06.020

Link to publication on Research at Birmingham portal

\begin{abstract}
General rights
Unless a licence is specified above, all rights (including copyright and moral rights) in this document are retained by the authors and/or the copyright holders. The express permission of the copyright holder must be obtained for any use of this material other than for purposes permitted by law.
\end{abstract}

- Users may freely distribute the URL that is used to identify this publication.

- Users may download and/or print one copy of the publication from the University of Birmingham research portal for the purpose of private study or non-commercial research.

- User may use extracts from the document in line with the concept of 'fair dealing' under the Copyright, Designs and Patents Act 1988 (?)

- Users may not further distribute the material nor use it for the purposes of commercial gain.

Where a licence is displayed above, please note the terms and conditions of the licence govern your use of this document.

When citing, please reference the published version.

Take down policy

While the University of Birmingham exercises care and attention in making items available there are rare occasions when an item has been uploaded in error or has been deemed to be commercially or otherwise sensitive.

If you believe that this is the case for this document, please contact UBIRA@lists.bham.ac.uk providing details and we will remove access to the work immediately and investigate. 


\section{Accepted Manuscript}

Isotopic signatures in atmospheric particulate matter suggest important contributions from recycled gasoline for lead and non-exhaust traffic sources for copper and zinc in aerosols in London, United Kingdom

Shuofei Dong, Raquel Ochoa Gonzalez, Roy M. Harrison, David Green, Robin North,

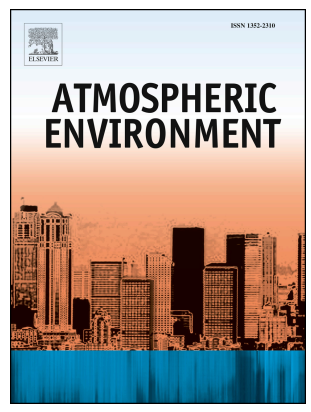

Geoff Fowler, Dominik Weiss

PII:

$$
\text { S1352-2310(17)30401-6 }
$$

DOI:

$$
\text { 10.1016/j.atmosenv.2017.06.020 }
$$

Reference: $\quad$ AEA 15382

To appear in: Atmospheric Environment

Received Date: 2 February 2017

Revised Date: 6 June 2017

Accepted Date: 10 June 2017

Please cite this article as: Dong, S., Ochoa Gonzalez, R., Harrison, R.M., Green, D., North, R., Fowler, G., Weiss, D., Isotopic signatures in atmospheric particulate matter suggest important contributions from recycled gasoline for lead and non-exhaust traffic sources for copper and zinc in aerosols in London, United Kingdom, Atmospheric Environment (2017), doi: 10.1016/j.atmosenv.2017.06.020.

This is a PDF file of an unedited manuscript that has been accepted for publication. As a service to our customers we are providing this early version of the manuscript. The manuscript will undergo copyediting, typesetting, and review of the resulting proof before it is published in its final form. Please note that during the production process errors may be discovered which could affect the content, and all legal disclaimers that apply to the journal pertain. 
Isotopic signatures in atmospheric particulate matter suggest important contributions from recycled gasoline for lead and non-exhaust traffic sources for copper and zinc in aerosols in London, United Kingdom

Shuofei Dong ${ }^{1,2}$, Raquel Ochoa Gonzalez ${ }^{1 *}$, Roy M. Harrison ${ }^{3,4}$, David Green ${ }^{5}$, Robin North ${ }^{6}$, Geoff 13 Fowler $^{1}$ and Dominik Weiss ${ }^{1}$

*Corresponding author

27 E-mail: raquelocglez@yahoo.es

28 Tel: +44 (0)20 75946383 


\section{Abstract}

33 The aim of this study was to improve our understanding of what controls the isotope composition of $\mathrm{Cu}, \mathrm{Zn}$ 34 and $\mathrm{Pb}$ in particulate matter (PM) in the urban environment and to develop these isotope systems as possible 35 source tracers. To this end, isotope ratios $(\mathrm{Cu}, \mathrm{Zn}$ and $\mathrm{Pb})$ and trace element concentrations $(\mathrm{Fe}, \mathrm{Al}, \mathrm{Cu}, \mathrm{Zn}, \mathrm{Sb}$, $36 \mathrm{Ba}, \mathrm{Pb}, \mathrm{Cr}, \mathrm{Ni}$ and $\mathrm{V}$ ) were determined in $\mathrm{PM}_{10}$ collected at two road sites with contrasting traffic densities in central London, UK, during two weeks in summer 2010, and in potential sources, including non-combustion traffic emissions (tires and brakes), road furniture (road paint, manhole cover and road tarmac surface) and road dust. The isotope signatures of other important sources (gasoline and exhaust emissions) were taken from previous published data. Iron, $\mathrm{Ba}$ and $\mathrm{Sb}$ were used as proxies for emissions derived from brake pads, and $\mathrm{Ni}$, and $\mathrm{V}$ for emissions derived from fossil fuel oil.

The isotopic composition of $\mathrm{Pb}$ (expressed using ${ }^{206} \mathrm{~Pb} /{ }^{207} \mathrm{~Pb}$ ) ranged between 1.1137 and 1.1364. The isotope ratios of $\mathrm{Cu}$ and $\mathrm{Zn}$ expressed as $\delta^{65} \mathrm{Cu}_{\text {NIST976 }}$ and $\delta^{66} \mathrm{Zn}_{\text {Lyon }}$ ranged between $-0.01 \%$ and $+0.51 \%$ and between $-0.21 \%$ and $+0.33 \%$, respectively. We did not find significant differences in the isotope signatures in $\mathrm{PM}_{10}$ over the two weeks sampling period and between the two sites, suggesting similar sources for each metal at both sites despite their different traffic densities. The stable isotope composition of $\mathrm{Pb}$ suggests significant contribution from road dust resuspension and from recycled leaded gasoline. The $\mathrm{Cu}$ and $\mathrm{Zn}$ isotope signatures of tires, brakes and road dust overlap with those of $\mathrm{PM}_{10}$. The correlation between the enrichments of $\mathrm{Sb}, \mathrm{Cu}, \mathrm{Ba}$ and $\mathrm{Fe}$ in $\mathrm{PM}_{10}$ support the previously established hypothesis that $\mathrm{Cu}$ isotope ratios are controlled by non-exhaust traffic emission sources in urban environments (Ochoa Gonzalez et al., 2016). Analysis of the $\mathrm{Zn}$ isotope signatures in $\mathrm{PM}_{10}$ and possible sources at the two sites suggests significant contribution from tire wear. However, temporary additional sources, likely high temperature industrial emissions, need to be invoked to explain the isotopically light $\mathrm{Zn}$ found in 3 out of 18 samples of $\mathrm{PM}_{10}$. 


\section{Introduction}

Metals in atmospheric particulate matter (PM) are a serious concern as they induce adverse health effects. Cardiopulmonary diseases have been attributed to the capacity of inhaled particles and metals to cause inflammation and injury at the air-lung interface (Costa and Dreher, 1997; Chen and Lippmann, 2009; Gamble and Lewis, 1996; Jarup, 2003; Ozkaynak et al., 1996). Lead exposure damages the human central nervous system and kidneys, affects biochemical processes and impairs psychological and neurobehavioral functions (Tong et al., 2000). Zinc is associated with oxidative stress and a contributing factor in many chronic diseases (Prasad et al., 2004; Walsh et al., 1994), and Cu causes damage to proteins and lipids (Brewer, 2010). Thus, developing a full understanding of the major sources of metals in urban PM is critical to control toxic emissions in urban environments.

Previous studies analyzed the sources of multiple elements in urban PM by using conventional chemical techniques and receptor modeling methods such as principal component analysis (PCA) and positive matrix factorization (PMF). These suggested that industrial emissions, exhaust and non-exhaust traffic emissions and resuspended road dust are the major sources that contribute to the metal aerosol burden in large cities around the world including Birmingham, Thessaloniki, and Boston (Cooper and Watson, 1980; Harrison et al., 1997; Laden et al., 2000; Lin et al., 2010; Manoli et al., 2002; Polissar et al., 2001; Querol et al., 2001; Thurston and Spengler, 1985). Iron and $\mathrm{Cr}$ are often associated with the bulk matrix from road dust, $\mathrm{Zn}$ from tire and brake wear, and road dust re-suspension, $\mathrm{Pb}$ from the past use of leaded gasoline, Fe from brake drum abrasion, wear-off of engines, tires and brakes, and $\mathrm{V}$ and $\mathrm{Ni}$ with emissions from oil combustion (Garg et al., 2000; Hjortenkrans et al., 2007; Manoli et al., 2002; Thorpe et al. 2007; Thurston et al., 2011). Copper, Sb and $\mathrm{Ba}$ are abundant in brake lining materials whereas brakes, yellow road paint and road pavement are typically sources of $\mathrm{Cr}$ (Adachi and Tainosho, 2004; Garg et al., 2000; Hjortenkrans et al., 2007; Iijima et al., 2007; Rodriguez et al., 2004; Salma and Maenhaut, 2006; Thorpe and Harrison, 2008).

The success of using metal concentrations in combination with PCA and PMF to identify single sources of trace metals remains limited. PCA does not provide a unique solution because of its simplified approach and the results of PMF vary depending on different uncertainty structures (Samek et al., 2016). Consequently, the use of isotope ratios is widely investigated to improve source tracing in atmospheric particles (Wiederhold, 2015, Weiss et al., 2008). This approach was indeed highly successful for $\mathrm{Pb}$, where isotopes identified leaded gasoline as the main source in urban PM in London, and despite the restrictions in the use of leaded gasoline in the 1980s, a contribution of 60\% was still found in west London between 1995 and 1996 (Monna et al., 1997; Noble et al., 2008). Stable isotope systems have been tested for source apportionment of trace elements in PM such as Fe, Sr, Zn and Nd (Flament et al., 2008; Geagea et al., 2008; Majestic et al., 2009; Widory et al., 2010). Zinc isotopes in urban PM were studied in Metz (Cloquet et al., 2006), São Paulo (Gioia et al., 2008), and Barcelona and London (Ochoa Gonzalez et al., 2016). In Metz, the $\delta^{66} \mathrm{Zn}_{\text {Lyon }}$ in ambient PM collected in a bus and an urban waste incinerator showed similar values close to $+0.12 \%$. In São Paolo, in contrast, Gioia et al. (2008) found lighter ratios and significantly larger variations in $\delta^{66} \mathrm{Zn}_{\text {Lyon }}$, ranging between -1.05 and $-0.46 \%$ in $\mathrm{PM}_{2.5-10}$ and between -1.13 and $-0.07 \%$ in $\mathrm{PM}_{2.5}$. In line with these findings, Ochoa Gonzalez et al. (2016) found isotopically light $\mathrm{Zn}$ in $\mathrm{PM}_{10}$ collected in Barcelona, with $\delta^{66} \mathrm{Zn}_{\text {Lyon }}$ ranging between -0.45 and $-0.83 \%$, and isotopically heavy $\mathrm{Cu}$ in coarse PM collected in London during late autumn 
and the winter season $\left(\delta^{65} \mathrm{Cu}_{\text {NIST976 }}\right.$ between +0.66 and $+0.97 \%$ ) (Ochoa Gonzalez et al., 2016). The observed isotope signatures in the PM were associated with sources derived from combustion and smelting processes. Other studies are in line with this interpretation as they showed that residues and flue gas particles from metal refining and coal combustion are highly fractionated relative to the starting materials, with isotopically lighter $\mathrm{Zn}$ emitted in the PM (between -0.73 and $-0.63 \%$ ) and heavy $\mathrm{Zn}$ remaining in the residues (up to $+1.49 \%$ ) (Mattielli et al., 2009; Ochoa Gonzalez and Weiss, 2015; Sivry et al., 2008). These signatures seem to partially overlap with the isotope ratios of $\mathrm{Zn}$ in anthropogenic materials produced during low temperature processes like galvanisation which show $\delta^{66} \mathrm{Zn}_{\text {Lyon }}$ between +0.12 and $+1.15 \%$ (Araújo et al., 2017; John et al, 2007). In summary, these studies suggested strongly that $\mathrm{Cu}$ and $\mathrm{Zn}$ isotopes can play an important role in the identification of emission sources from metal refining and combustion due to their larger fractionation, as well as $\mathrm{Pb}$ isotopes to assess the contribution from the past use of leaded gasoline.

The aim of this study was to improve our present knowledge on what controls the isotopic variability of $\mathrm{Cu}$, $\mathrm{Zn}$ and $\mathrm{Pb}$ in urban $\mathrm{PM}$ and to critically assess the potential of these isotope systems for source tracing. To this end, we determined short-term temporal and spatial isotope variability of $\mathrm{Cu}, \mathrm{Zn}$ and $\mathrm{Pb}$ in $\mathrm{PM}_{10}$ collected in 2010 in central London and in potential sources including road furniture (manhole cover, road paint and road tarmac surface), non-combustion vehicle sources (tire and brake wear) and road dust (that represents other potential sources deposited in the road environment). We collected possible sources and $\mathrm{PM}_{10}$ samples at a high and a low traffic density site over a 20-day sampling period during summer. The concentrations of trace elements including $\mathrm{Fe}, \mathrm{Sb}, \mathrm{Ba}, \mathrm{Cr}, \mathrm{Ni}$, and $\mathrm{V}$, and enrichment factors (EF) were combined with the isotope ratios of $\mathrm{Zn}$, $\mathrm{Cu}$ and $\mathrm{Pb}$ to constrain possible contributions from sources. Finally, we critically compare the isotope data in $\mathrm{PM}_{10}$ and potential sources in London with previously published isotope signatures of other potential sources and PM from major urban cities.

\section{Materials and methods}

\subsection{Sample collection}

Samples of $\mathrm{PM}_{10}$ were collected for $48 \mathrm{~h}$ using a Partisol-Plus Model 2025 Sequential Air Sampler (Thermo Scientific, MA, USA) at two different road sites in central London between $8^{\text {th }}$ July 2010 and $28^{\text {th }}$ July 2010 at a height of $3.5 \mathrm{~m}$. Nine samples (MR1-MR9) were collected at the heavily traffic street canyon Marylebone Road (denoted as MR) in London, with more than 80,000 vehicles per day and frequently congested (Charron and Harrison, 2005). Nine samples (NK1-NK9) were collected at a sampling location in North Kensington (denoted as NK) which is a lightly trafficked open urban site situated next to a school playground (Bigi and Harrison, 2010). The sampling site NK has an average daily traffic flow of 8,000 vehicles and the nearest road is more than $30 \mathrm{~m}$ away (Abdalmogith and Harrison, 2006). Polytetrafluoroethylene (PTFE) filters were used for $\mathrm{PM}_{10}$ collection and leached prior use for 2 days in $1.5 \mathrm{M}$ sub-boiling distilled $\mathrm{HNO}_{3}$ at $100^{\circ} \mathrm{C}$ on a hotplate.

Potential ssources for various metals were constrained following a critical literature review and included brake pads for $\mathrm{Cu}, \mathrm{Sb}$ and $\mathrm{Ba}$; tire wear and road dust for $\mathrm{Zn}, \mathrm{Fe}, \mathrm{Pb}$ and $\mathrm{Cr}$; road paint and road surface for $\mathrm{Cr}$ (Adachi and Tainosho, 2004; Hjortenkrans et al., 2007; Thorpe and Harrison, 2008; Thorpe et al., 2007), and exhaust emissions have been taken from the literature (Cloquet et al., 2006; Gioia et al., 2008; Monna et al., 
1997).

Three samples of road dust were taken at each site, one next to the PM sampling tube and two in the opposite directions from each sampling site. Approximately $30 \mathrm{~g}$ of road dust were taken using a brush and a pan previously cleaned; samples were sieved at $2 \mathrm{~mm}$ and then milled using an agate pestle and mortar for subsequent analysis. The road dust samples were taken during clear days without rainfall $24 \mathrm{~h}$ prior sample collection. Road furniture (manhole cover and road paint, two samples at each site; road tarmac surface, two samples at the NK site) were sampled within approximately $10 \mathrm{~m}$ of each aerosol sampling site and were stored in plastic bags. There were no natural soils exposed close to the sampling sites. There were manhole covers in the middle of the roads where the $\mathrm{PM}_{10}$ were collected, as well on the side. There were approximately five manhole covers within $50 \mathrm{~m}$.

Non-combustion vehicle sources, i.e., tear-off from tires and brakes, were characterized using a collection of used tires and new brake pads. Twelve individual car tires of common commercial brands were shredded and mixed in three sets (labelled as R43/54-1, R43/54-2 and R56/57-1) before analysis. The brake samples were scratched from the surface of two different brands of metallic brake pads commonly used. These include metallic pads HBP Ferodo for Peugeot and Renault cars, and FSB Halfords for Volkswagen family cars (labelled as HBP and FSB, respectively).

\subsection{Sample preparation}

The filters were weighed before and after the collection to determine the mass of material. The metals were leached from the filter with $5 \mathrm{ml}$ of aqua regia for 24 hours followed by $10 \mathrm{ml}$ of $0.5 \mathrm{M} \mathrm{HNO}_{3}$ for 48 hours on a hotplate at $80^{\circ} \mathrm{C}$. An ultrasonic bath was used for 1 hour every 12 hours to improve the removal efficiency. The filters were then washed with $5 \mathrm{ml} 0.5 \mathrm{M} \mathrm{HNO}_{3}$ three times. The two solutions were mixed and evaporated to dryness before further treatment. The standard reference material BCR-723 (road dust) and all the samples were digested using a conc. $\mathrm{HNO}_{3}: \mathrm{HClO}_{4}$ mixture (1:4) in sealed PFA vials (Savillex, MN, USA) at $150^{\circ} \mathrm{C}$ in a hotplate for 24 hours. $\mathrm{HClO}_{4}$ was used to favor the oxidation of the organic matter. The samples were dried and digested using a mixture of conc. $\mathrm{HNO}_{3}$ and $\mathrm{HF}(1: 4)$ on a hotplate at $140^{\circ} \mathrm{C}$ for another 24 hours. The solutions were taken to dryness again. The samples were re-fluxed in $300 \mu 1$ of conc. $\mathrm{HNO}_{3}$ and evaporated twice to remove the excess of fluorides. After re-dissolution in $2.5 \mathrm{ml}$ of $0.5 \mathrm{M} \mathrm{HNO}_{3}, 0.5 \mathrm{ml}$ was used for concentration measurement using quadrupole ICP-MS and the remaining volume of each solution was prepared for anion exchange column separation of $\mathrm{Pb}, \mathrm{Cu}$ and $\mathrm{Zn}$.

All the experimental work was carried out in a Class 1000 clean lab and under Class 10 laminar flow hoods in the MAGIC laboratories at Imperial College London. Sub-distilled mineral acids $\left(\mathrm{HNO}_{3} 15 \mathrm{~mol} \mathrm{l}^{-1}\right.$, $\mathrm{HCl} 6 \mathrm{~mol} \mathrm{l}^{-1}$ ), commercial HF (40 \% v/v Suprapur, Merck, Germany) and $\mathrm{HClO}_{4}(70 \%$ v/v Suprapur, Merck, Germany), and $18.2 \mathrm{M} \Omega \cdot \mathrm{cm}$ grade Millipore water (Bedford, MA, USA) were used throughout this study.

\subsection{Concentration analysis and enrichment factors}

The concentration of $\mathrm{Fe}, \mathrm{Al}, \mathrm{Cu}, \mathrm{Zn}, \mathrm{Sb}, \mathrm{Ba}, \mathrm{Pb}, \mathrm{Cr}, \mathrm{Ni}$ and $\mathrm{V}$ were determined using quadrupole ICP-MS (Varian, CA, USA). Table $\mathrm{S} 1$ shows the concentrations of $\mathrm{Cu}, \mathrm{Zn}, \mathrm{Sb}, \mathrm{Ba}$ and $\mathrm{Pb}$ determined for BCR-723 (road dust) and the indicative values provided by the European Commission Joint Research Centre Institute for Reference Materials and Measurements. The analytical uncertainty of the concentration determinations for all 
175 elements was better than $6 \%(\mathrm{n}=5,2 \mathrm{SD})$ and the recoveries, relative to the indicative values were higher than $17689 \%$ with respect to the reference values for all the elements.

177 The EFs of the $\mathrm{PM}_{10}$ were calculated to assist the source assessment study using $\mathrm{Al}$ as as a proxy for the 178 upper continental crust according to Eq. 1,

$$
\mathrm{EF}_{\mathrm{C}}=\frac{\mathrm{C}_{\text {sample }} / \mathrm{Al}_{\text {sample }}}{\mathrm{C}_{\text {crust }} / \mathrm{Al}_{\text {crust }}} \quad \text { [Eq. 1] }
$$

180 where $\mathrm{C}$ is the element of interest and $\mathrm{C}_{\text {sample }}, \mathrm{Al}_{\text {sample }}, \mathrm{C}_{\text {crust }}$ and $\mathrm{Al}_{\text {crust }}$ are the concentrations of $\mathrm{C}$ and $\mathrm{Al}$ in the 181 sample and the continental crust. The average chemical composition of the upper continental crust was used as 182 previously reported (Wedepohl, 1995).

\subsection{Isotope ratio analysis of $\mathrm{Cu}, \mathrm{Zn}$ and $\mathrm{Pb}$}

Copper, $\mathrm{Zn}$ and $\mathrm{Pb}$ in all of the samples were separated from other matrix elements using ion exchange chromatography. The details of the $\mathrm{Cu}, \mathrm{Zn}$ and $\mathrm{Pb}$ separation methods and sample treatment are described in detail elsewhere (Dong et al., 2013; Weiss et al., 2004) and summarized in the supplementary material. The isotope ratios were determined using a $\mathrm{Nu}$ Plasma multi collector ICP-MS (Nu Instruments Limited, UK) equipped with a Nu DSN-100 Desolvation Nebuliser System. The instrumental mass bias was corrected using standard-sample bracketing for $\mathrm{Cu}$ isotope ratio measurement (Peel et al. 2008), $\mathrm{Tl}$ doping for $\mathrm{Pb}$ isotope ratio measurements (Weiss et al., 2004) and a ${ }^{64} \mathrm{Zn}-{ }^{67} \mathrm{Zn}$ double spike for $\mathrm{Zn}$ isotope ratio measurements (Arnold et al., 2010, Ochoa Gonzalez et al., 2016).

The total procedural blank was $<4 \mathrm{ng}$ for $\mathrm{Cu}$ and $\mathrm{Zn}$, and $<80 \mathrm{pg}$ for $\mathrm{Pb}$. These contributions were less than $0.01 \%$ of the total element content in all samples analyzed and had no significant effect on the accuracy of the isotope ratio measurements. The Romil $\mathrm{Cu}$ and Romil $\mathrm{Zn}$ solutions were processed and measured with the samples and showed values of $\delta^{65} \mathrm{Cu}_{\mathrm{NIST} 976}=+0.17 \pm 0.10 \%$ o (2SD, $\left.\mathrm{n}=24\right)$ and $\delta^{66} \mathrm{Zn}_{\text {Lyon }}=-9.12 \pm 0.08 \%$ ( $2 \mathrm{SD}$, $\mathrm{n}=20)$, respectively. These are within error relative to previous published values for Romil $\mathrm{Cu}\left(\delta^{65} \mathrm{Cu}_{\mathrm{NIST} 976}=\right.$ $+0.18 \pm 0.06 \%$, $\mathrm{n}=19$, Moeller et al., 2012; $\delta^{65} \mathrm{Cu}_{\mathrm{NIST} 976}=+0.18 \pm 0.05 \%$, $\mathrm{n}=4$, Ochoa Gonzalez et al., 2016) and Romil $\mathrm{Zn}\left(\delta^{66} \mathrm{Zn}_{\text {Lyon }}=-9.14 \pm 0.08 \%\right.$ o, $\mathrm{n}=21$, Chapman et al., 2006). During this study ${ }^{206} \mathrm{~Pb} /{ }^{204} \mathrm{~Pb}$, ${ }^{207} \mathrm{~Pb} /{ }^{204} \mathrm{~Pb}$ and ${ }^{208} \mathrm{~Pb} /{ }^{204} \mathrm{~Pb}$ for NIST-SRM $981 \mathrm{~Pb}$ (when treated as non-spiked standard) were $16.9372 \pm$ $0.0021,15.4954 \pm 0.0021$ and $36.7158 \pm 0.0057(\mathrm{n}=50)$, respectively, which are in good agreement with previous published data (Weiss et al., 2004).

\section{Results and discussion}

\subsection{Source assessment based on concentrations and enrichment factors}

The concentrations of $\mathrm{PM}_{10}$ and of $\mathrm{Fe}, \mathrm{Cu}, \mathrm{Al}, \mathrm{Zn}, \mathrm{Sb}, \mathrm{Ba}, \mathrm{Fe}, \mathrm{Cr}, \mathrm{Pb}, \mathrm{Ni}$ and $\mathrm{V}$ in $\mathrm{PM}_{10}$ and local sources are shown in Table 1 and Table 2. The concentrations of $\mathrm{PM}_{10}$ are approximately twice as high at the MR site $\left(31 \pm 7 \mu \mathrm{g} \mathrm{m}^{-3}\right)$ compared to the NK site $\left(14 \pm 3 \mu \mathrm{g} \mathrm{m} \mathrm{m}^{-3}\right)$. According to London Air, average hourly concentrations of $\mathrm{PM}_{10}$ at the MR and NK sites over the sampling period during July 2010 are $40 \pm 15 \mu \mathrm{g} \mathrm{m}^{-3}$ and $16 \pm 7 \mu \mathrm{g} \mathrm{m}^{-3}$, respectively (London Air Website, www.londonair.org.uk).

The concentrations and EFs of $\mathrm{Fe}, \mathrm{Cu}, \mathrm{Zn}, \mathrm{Sb}, \mathrm{Ba}$ and $\mathrm{Cr}$ in the $\mathrm{PM}_{10}$ collected at the MR site are much higher than those at the NK site (Tables 1 and 3). These elements are highly enriched relative to natural dust 
represented geochemically by the upper continental crust (Table 3), suggesting that they are derived from traffic related emissions. Iron, $\mathrm{Cu}, \mathrm{Zn}, \mathrm{Sb}$ and $\mathrm{Ba}$ are typically high in tires and brakes (McKenzie et al., 2009). The correlations between the $\mathrm{EF}_{\mathrm{Sb}}$ and those of $\mathrm{Fe}, \mathrm{Cu}, \mathrm{Zn}$ and $\mathrm{Ba}$ (Figure 1) in $\mathrm{PM}_{10}$ at the $\mathrm{NK}$ and the MR sites show $\mathrm{R}^{2}$ between 0.8686 and 0.9972 , supporting the hypothesis of similar sources at the sampling sites and of non-combustion traffic emissions as main source. The $\mathrm{EF}_{\mathrm{Sb}}$ and those of typical tracers of brakes (i.e., $\mathrm{Fe}, \mathrm{Cu}$ and $\mathrm{Ba}$ ) show similar and very high $\mathrm{R}^{2}\left(\mathrm{R}^{2}\right.$ between 0.9949 and 0.9972$)$, suggesting that non-exhaust traffic emissions are the dominant source for these elements in urban $\mathrm{PM}_{10}$ in London.

Re-suspension of small particles of road dust may have a significant effect on the generation of $\mathrm{PM}_{10}$ enriched in metals (Amato et al., 2014; Thorpe and Harrison, 2008). The road dust samples collected at the MR site (MRRD-1, MRRD-2 and MRRD-3) are enriched in $\mathrm{Fe}, \mathrm{Cu}, \mathrm{Zn}, \mathrm{Sb}, \mathrm{Ba}, \mathrm{Cr}$ and $\mathrm{Pb}$ compared to road dust at the NK site (NKRD-1, NKRD-2 and NKRD-3) (Table 3), most probably reflecting the higher traffic density. This observation supports the idea that re-suspended road dust is an important source of these elements in urban PM (Amato et al., 2014).

Brake wear is the dominant source of Ba in urban and natural PM (Gietl and Klemm, 2009; Gietl et al., 2010; Iijima et al., 2007; Moreno et al., 2015). We find high concentrations of Ba in brakes $(310-1300 \mu \mathrm{g}$ $\mathrm{g}^{-1}$ ) and samples of manhole cover (120-1100 $\mu \mathrm{g} \mathrm{g}^{-1}$ ) (Table 2). The concentrations of Ba in the $\mathrm{PM}_{10}$ at the NK site $\left(1.6 \pm 0.4 \mathrm{ng} \mathrm{m}^{-3}\right)$ are much lower than at the MR site $\left(5.7-84 \mathrm{ng} \mathrm{m}^{-3}\right)$, supporting the dominant contribution of brake wear.

The concentration of $\mathrm{Zn}$ in $\mathrm{PM}_{10}$ ranges between 1.4 and $3.1 \mathrm{ng} \mathrm{m}^{-3}$ at the NK site, and between 3.7 and 41 $\mathrm{ng} \mathrm{m}^{-3}$ at the MR site. The concentration of $\mathrm{Cu}$ in $\mathrm{PM}_{10}$ ranges between 1.9 and $3.6 \mathrm{ng} \mathrm{m}^{-3}$ at the NK site and between 9.4 and $130 \mathrm{ng} \mathrm{m}^{-3}$ at the MR site. The element concentrations show that the content of $\mathrm{Zn}$ in tires and of $\mathrm{Cu}$ in brakes, tires and manhole cover are significantly higher than in other sources (Table 2). In addition, samples of road tarmac surface and manhole cover contain significant amounts of $\mathrm{Zn}$. $\mathrm{Cu} / \mathrm{Sb}$ ratios between 3.3 and 9.1 have been used to identify brake wear in PM collected in Cologne, London, Stockholm and Budapest (Hjortenkrans et al., 2007; Salma and Maenhaut, 2006; Weckwerth, 2001). In this study similar Cu/Sb ratios are observed in $\mathrm{PM}_{10}$, although with a smaller range between 5.8 and 8.3 (Table 1). The average $\mathrm{Cu} / \mathrm{Sb}$ ratios in the $\mathrm{PM}_{10}$ at the NK site are slightly higher than those in the $\mathrm{PM}_{10}$ at the MR site. However, the $\mathrm{Cu} / \mathrm{Sb}$ ratios in the studied brake pads range between 27 and 39 and are large compared with typical values for brakes in PM (Table 2). This observation is likely explained by the recent restrictions on the use of $\mathrm{Sb}_{2} \mathrm{~S}_{3}$ during the manufacturing process of brake pads due to its potential carcinogenic properties (Hüner et al., 2001).

The concentrations of $\mathrm{Cr}$ in $\mathrm{PM}_{10}$ collected at the MR site $\left(0.9-8.2 \mathrm{ng} \mathrm{m}^{-3}\right)$ are higher than those at the NK site $\left(0.3 \pm 0.1 \mathrm{ng} \mathrm{m}^{-3}\right)$. Multiple sources including brakes, manhole cover, yellow road paint (NKRP-2) and road dust are enriched in this element relative to natural dust (Table 3). However, the positive correlation between the $\mathrm{EF}_{\mathrm{Sb}}$ and the $\mathrm{EF}_{\mathrm{Cr}}\left(\mathrm{R}^{2}=0.9385\right)$ in $\mathrm{PM}_{10}$ (Figure 1), and between the $\mathrm{EF}_{\mathrm{Sb}}$ and those of other elements linked with non-exhaust traffic emissions, i.e., $\mathrm{Cu}, \mathrm{Ba}$, and $\mathrm{Fe}$, suggests that not only $\mathrm{Cu}, \mathrm{Ba}$ and $\mathrm{Fe}$, but also $\mathrm{Cr}$ is mainly controlled by non-exhaust traffic emissions in the urban atmosphere. The concentrations of $\mathrm{Fe}$ and $\mathrm{EF}_{\mathrm{Fe}}$ in the $\mathrm{PM}_{10}$ collected at $\mathrm{MR}$ are higher than those in the $\mathrm{PM}_{10}$ at $\mathrm{NK}$, and significantly larger concentrations of this element are found in samples of brakes and manhole cover. In addition to these sources, brake discs contribute significantly to $\mathrm{PM}_{10}$ enriched in Fe (Wåhlin et al., 2006).

The elemental concentrations and $\mathrm{EF}$ of $\mathrm{Ni}$ and $\mathrm{V}$ are similar in the $\mathrm{PM}_{10}$ at both sites, which suggests that 
these elements are not directly affected by the density of traffic (Tables 1 and 3). Previous studies suggested that $\mathrm{Ni}$ and $\mathrm{V}$ are mainly derived from fuel oil, gas refineries, and industrial processes (Moreno et al., 2010; Nriagu and Pacyna, 1988; Peltier and Lippmann, 2010), and less from non-exhaust traffic sources (Thorpe and Harrison, 2008). In a recent receptor modeling study conducted using $\mathrm{PM}_{10}$ samples collected at the NK site (Beddows et al., 2015), Ni and V were found to be associated with high concentrations of sulphate in a fuel oil-related factor.

Lead concentrations in $\mathrm{PM}_{10}$ are slightly higher at the MR site $\left(1.1-8.8 \mathrm{ng} \mathrm{m}^{-3}\right)$ compared to the NK site $\left(1.0 \pm 0.3 \mathrm{ng} \mathrm{m}^{-3}\right)$ but the $\mathrm{EF}_{\mathrm{Pb}}$ are similar at both sites. Some studies based on emissions of metals in $\mathrm{PM}_{10}$ and $\mathrm{PM}_{2.5}$ suggested that following the phasing out of leaded gasoline, $\mathrm{Pb}$ is emitted into the urban atmosphere from fuel and motor oil combustion or brake wear (Lough et al., 2005). Significantly high concentrations of $\mathrm{Pb}$ relative to other possible sources have been found in tires and brakes $\left(4.0-38 \mu \mathrm{g} \mathrm{g}^{-1}\right)$ and in manhole covers $\left(56-690 \mu \mathrm{g} \mathrm{g}^{-1}\right)$ (Table 2).

\subsection{Source identification of lead using stable isotope ratios}

The ${ }^{206} \mathrm{~Pb}^{1204} \mathrm{~Pb},{ }^{206} \mathrm{~Pb}^{1207} \mathrm{~Pb}$ and ${ }^{208} \mathrm{~Pb}^{1206} \mathrm{~Pb}$ isotope ratios determined in the $\mathrm{PM}_{10}$ and the sources are shown in Table 4. Figure $2 \mathrm{a}$ shows that the $\mathrm{Pb}$ isotope ratios in $\mathrm{PM}_{10}$ are similar at the MR and NK sites. This observation, and similarity between the $\mathrm{EF}_{\mathrm{Pb}}$ in the $\mathrm{PM}_{10}$ at the MR and NK sites (Table 1), suggest that the source(s) at $\mathrm{NK}$ and MR sites are the same. The $\mathrm{Pb}$ isotope ratios measured in the $\mathrm{PM}_{10}$ at $\mathrm{NK}\left({ }^{206} \mathrm{~Pb}^{1204} \mathrm{~Pb}=\right.$ 17.446-17.598, ${ }^{206} \mathrm{~Pb}^{1207} \mathrm{~Pb}=1.1218-1.1304,{ }^{208} \mathrm{~Pb}^{1206} \mathrm{~Pb}=2.1288-2.1382$ ) fall within the respective ranges at MR $\left({ }^{206} \mathrm{~Pb}{ }^{1204} \mathrm{~Pb}=17.305-17.701,{ }^{206} \mathrm{~Pb}{ }^{1207} \mathrm{~Pb}=1.1137-1.1364,{ }^{208} \mathrm{~Pb}^{1206} \mathrm{~Pb}=2.1246-2.1476\right)$. These $\mathrm{Pb}$ signatures are significantly different from those of natural sources in the $\mathrm{UK}\left({ }^{206} \mathrm{~Pb}^{1207} \mathrm{~Pb}=1.18-1.19\right.$, Monna et al., 1997), which suggests an ongoing contribution of anthropogenic sources of $\mathrm{Pb}$ in atmospheric $\mathrm{PM}$. The ${ }^{208}{ }^{\mathrm{Pb}}{ }^{1206} \mathrm{~Pb}$ and ${ }^{206} \mathrm{~Pb}^{1207} \mathrm{~Pb}$ isotope ratios determined in our study are similar to those reported in 1995,1998 and 1999 and partly overlap with years 1996, 2000 and 2001 (Monna et al., 1997; Noble et al., 2008) (Figure 2b). The ${ }^{206} \mathrm{~Pb}^{1207} \mathrm{~Pb}$ determined for urban $\mathrm{PM}_{10}$ in our study fall within the range determined in France and the UK during mid-90s, that ranged between 1.1008 and 1.1453 (Monna et al., 1997). Noble et al. (2008) showed that since leaded gasoline was banned in the UK in 1998 , the ${ }^{206} \mathrm{~Pb}^{1207} \mathrm{~Pb}$ isotope ratio in urban $\mathrm{PM}$ in London shifted slightly from $1.1169-1.1388$ to more radiogenic ratios during 2000 and 2001, and they stabilized thereafter $(1.1354-1.1507)$. The isotope ratios of road paint $\left({ }^{206} \mathrm{~Pb}^{1204} \mathrm{~Pb}=17.866-18.301,{ }^{206} \mathrm{~Pb}{ }^{1207} \mathrm{~Pb}=\right.$ $\left.1.1471-1.1708,{ }^{208} \mathrm{~Pb}{ }^{1206} \mathrm{~Pb}=2.0843-2.1012\right)$ and of road dust $\left({ }^{206} \mathrm{~Pb}^{1204} \mathrm{~Pb}=17.347-17.890,{ }^{206} \mathrm{~Pb}^{1207} \mathrm{~Pb}=\right.$ $\left.1.1163-1.1417,{ }^{208} \mathrm{~Pb}^{1206} \mathrm{~Pb}=2.1176-2.1446\right)$ collected at the two sampling sites show significant $\mathrm{Pb}$ isotope ratio variability. As illustrated in Figure $2 \mathrm{a}$, the $\mathrm{Pb}$ isotope ratios of the $\mathrm{PM}_{10}$ fall on a mixing line with gasoline used in the UK before its phasing out as one end member (Monna et al., 1997), and road dust which contains re-mobilized $\mathrm{Pb}$ from leaded gasoline and other source deposits such as tires, brakes and road furniture as the other end member. The $\mathrm{Pb}$ isotope composition of the $\mathrm{PM}_{10}$ collected at $\mathrm{NK}$ and MR sites is similar to those of road dust and manhole cover which suggests that re-suspended road dust may contribute to $\mathrm{Pb}$ enrichment in urban $\mathrm{PM}$. Previous elemental analyses of $\mathrm{PM}_{10}$ from the NK site showed appreciable concentrations of crustal elements such as $\mathrm{Al}$ and $\mathrm{Ca}$, that might have arisen from road dust (Beddows et al., 2015). Therefore, it seems likely that road dust with residual contamination from the earlier use of leaded gasoline contribute to $\mathrm{PM}_{10}$ due to resuspension into the atmosphere. 


\subsection{Copper and zinc isotope ratios variations in source materials and $\mathbf{P M} \mathbf{M}_{10}$}

The $\mathrm{Cu}$ and $\mathrm{Zn}$ isotope ratios of $\mathrm{PM}_{10}$ collected at the sites with high and low traffic densities and the potential local sources are illustrated in Figure 3. Previous published data for $\mathrm{PM}_{2.5-80}$ collected in London between 2014 and 2015 and for $\mathrm{PM}_{10}$ collected in Barcelona between 2012 and 2013 (Ochoa Gonzalez et al., 2016) are shown for reference. The $\delta^{65} \mathrm{Cu}_{\text {NIST976 }}$ values vary in the range between $+0.01 \pm 0.13 \%$ and $+0.51 \pm 0.10 \%$ at the MR site and between $-0.01 \pm 0.10 \%$ and $+0.46 \pm 0.07 \%$ at the NK site which suggests same sources of $\mathrm{Cu}$ in the $\mathrm{PM}_{10}$ collected at the two sampling sites (Table S2-Sn). This agrees with our hypothesis derived from the linear correlations between the $\mathrm{EF}$ of typical tracers of non-exhaust emissions (i.e. $\mathrm{Cu}, \mathrm{Sb}, \mathrm{Ba}, \mathrm{Zn}$ and $\mathrm{Fe}$ ) in $\mathrm{PM}_{10}$ (Figure 1). The $\delta^{66} \mathrm{Zn}_{\text {Lyon }}$ values in $\mathrm{PM}_{10}$ collected at the MR site range between $-0.14 \pm 0.04 \%$ and $+0.33 \pm 0.04 \%$, and at the NK site between $-0.21 \pm 0.14 \%$ ond $+0.26 \pm 0.12 \%$. We do not observe a significant temporal trend in the isotope composition during the sampling period of 20 days and there is no correlation between the shifts in the isotopic composition of $\mathrm{Cu}$ and those of $\mathrm{Zn}$ (Table S2-Sn). The latter observation probably reflects different contribution from the non-exhaust traffic sources of $\mathrm{Zn}$ and those of $\mathrm{Cu}$. Although higher $\mathrm{Cu}$ and $\mathrm{Zn}$ concentrations are found at the high traffic site (Table 1), the isotope data set suggests that the dominant sources and/or controlling processes are the same at both sites studied. The similar variability in the $\mathrm{Cu}$ and $\mathrm{Zn}$ isotope ratios in the $\mathrm{PM}_{10}$ collected at the low and high traffic sites during 3 weeks over July 2010 (Figure 3) suggests that the sources of $\mathrm{Cu}$ and $\mathrm{Zn}$ in $\mathrm{PM}_{10}$ do not change on that temporal and spatial scale. This observation is in good agreement with previous studies over an entire year that showed only significant $\mathrm{Cu}$ isotope variability during the winter season and suggested that traffic sources are the main contributor to $\mathrm{Cu}$ and $\mathrm{Zn}$ enrichment in $\mathrm{PM}_{2.5-80}$ (Ochoa Gonzalez et al., 2016) and $\mathrm{PM}_{2.5-10}$ (Visser et al., 2015) in London. The $\mathrm{Cu}$ and $\mathrm{Zn}$ isotope ratios of $\mathrm{PM}_{2.5-80}$ collected at building height during July and August 2014 and July and August 2015 showed $\delta^{65} \mathrm{Cu}_{\text {NIST976 }}$ between $+0.46 \pm 0.12 \%$ and $+0.55 \pm 0.15 \%$ and $\delta^{66} \mathrm{Zn}_{\text {Lyon }}$ between $+0.02 \pm 0.04 \%$ and $+0.17 \pm 0.02 \%$, with one light sample collected during summer $2015\left(\delta^{66} \mathrm{Zn}_{\text {Lyon }}=\right.$ $-0.29 \pm 0.04 \%$ ) (Ochoa Gonzalez et al., 2016). The $\mathrm{Cu}$ and $\mathrm{Zn}$ isotope signatures in $\mathrm{PM}_{10}$ collected in London at the NK and MR sites during 2010 in London agree well with the isotope signatures in $\mathrm{PM}_{2.5-80}$ collected in another street canyon during 2014 and 2015 in the same city (Ochoa Gonzalez et al., 2016).

\subsubsection{Controls of copper isotope signatures in urban particulate matter in London}

Brakes, tires, manhole cover, road paint, and road tarmac surface have $\delta^{65} \mathrm{Cu}_{\text {NIST976 }}$ values ranging between $-0.18 \pm 0.14 \%$ and $+0.71 \pm 0.09 \%$ (Table S2-Sn). Four out of the six road dust samples show $\mathrm{Cu}$ isotope signatures falling within this range and two samples show more negative isotope signatures $\left(\delta^{65} \mathrm{Cu}_{\mathrm{NBS976}}=\right.$ $-0.28 \pm 0.08 \%$ and $-0.22 \pm 0.08 \%$ o) at the MR site. Isotopically heavy $\mathrm{Cu}$ is found in road paint, road tarmac surface and selected samples of brakes and manhole cover, with $\delta^{65} \mathrm{Cu}_{\mathrm{NBS976}}$ values above $+0.55 \%$. The $\delta^{65} \mathrm{Cu}_{\text {NIST976 }}$ of the non-exhaust traffic sources (i.e., tires and brakes) show significant isotope variability, ranging between $+0.17 \pm 0.10 \%$ and $+0.33 \pm 0.12 \%$ o for tires and between $+0.28 \pm 0.10 \%$ ond $+0.63 \pm 0.14 \%$ o for brakes, most probably reflecting the different $\mathrm{Cu}$ species such as metallic $\mathrm{Cu}, \mathrm{Cu}$ oxides or $\mathrm{Cu}$ sulfides (Grigoratos and Martini, 2015; Straffelini et al., 2015), the different geographical location of the ores used and/or possible isotopic fractionation during the manufacturing processes.

$\mathrm{Cu} / \mathrm{Sb}$ ratios in the PM have been used to identify source contribution of brake wear in urban PM 
333 (Hjortenkrans et al., 2007; Salma and Maenhaut, 2006; Weckwerth, 2001). The relationship between Cu/Sb ratios and the $\mathrm{Cu}$ isotope composition in the samples of PManalysed during this work and a previous study conducted in Barcelona and London (Ochoa Gonzalez et al., 2016) is illustrated in Figure 4. The $\mathrm{PM}_{10}$ samples from Barcelona and London with low $\mathrm{Cu} / \mathrm{Sb}$ ratios ranging between 5.8 and 12, which fall within the range of $\mathrm{Cu} / \mathrm{Sb}$ found for brakes, have isotopically lighter $\mathrm{Cu}$ with $\delta^{65} \mathrm{Cu}_{\mathrm{NBS} 976}$ ranging between -0.01 and $+0.51 \%$ o Indeed, these isotope signatures largely overlap with the $\mathrm{Cu}$ isotope signatures in samples of brakes analyzed during this study $\left(\delta^{65} \mathrm{Cu}_{\text {NIST976 }}=+0.28 \pm 10 \% o-+0.63 \pm 14 \%\right.$ ) (Table S2-Sn). Coarse particles $\left(\mathrm{PM}_{2.5-80}\right)$ in London with $\mathrm{Cu} / \mathrm{Sb}$ ratios larger than 12 and isotopically heavier $\mathrm{Cu}\left({ }^{65} \mathrm{Cu}_{\text {NIST976 }}\right.$ ranging between +0.63 and $+0.97 \%$ ) were attributed to particles emitted during fossil fuel combustion emissions which seemed more important during end-autumn and the winter season (Ochoa Gonzalez et al., 2016).

\subsubsection{Controls of zinc isotope signatures in urban particulate matter in London}

Brakes, tires, manhole cover, road paint, and road tarmac surface show $\delta^{66} \mathrm{Zn}_{\text {Lyon }}$ ranging between $-0.02 \pm 0.09 \%$ o and $+0.58 \pm 0.10 \%$ (Table S2-Sn). The $\mathrm{Zn}$ isotope signatures of the samples of road dust range between $+0.21 \pm 0.05 \%$ and $+0.34 \pm 0.10 \%$ at both sites, except one sample with a $\delta^{66} \mathrm{Zn}_{\text {Lyon }}$ of $-0.03 \pm 0.08 \%$ at the NK site. These ratios overlap with the signatures in $\mathrm{PM}_{10}$ at the $\mathrm{NK}$ and MR sites. The variations in the $\mathrm{Zn}$ isotope signatures found in the road dust samples at the two sites likely reflect the potential accumulation of different sources. Manhole cover, road paint and road surface show significant isotope variability within each source type, up to $0.51 \%$. This suggests that the source materials and/or processes during the manufacturing of these products have an effect on the isotope variability of each kind of source. The isotopically heaviest $\mathrm{Zn}$ has been measured in road paint $\left(\delta^{66} \mathrm{Zn}_{\text {Lyon }}\right.$ between +0.07 and $+0.58 \%$, $\left.\mathrm{n}=4\right)$. The $\mathrm{Zn}$ isotope composition of brakes and tires vary within a small range with $\delta^{66} \mathrm{Zn}_{\text {Lyon }}$ between $+0.15 \pm 0.07 \%$ and $+0.21 \pm 0.08 \%$ o $(\mathrm{n}=6)$ and are not significantly different relative to an average internal precision of $0.08 \%$. Together with the high levels of $\mathrm{Zn}$ in tires (Table 2), we propose that $\mathrm{Zn}$ in most of the $\mathrm{PM}_{10}$ sampled at the NK and the MR sites $\left(\delta^{66} \mathrm{Zn}_{\text {Lyon }}\right.$ ranging between $-0.04 \pm 0.14 \%$ and $+0.33 \pm 0.04 \%$ ) are derived from tires (Figure 3 ). However, a source enriched in isotopically light $\mathrm{Zn}$ which can explain the $\mathrm{Zn}$ isotope signatures found in three samples of $\mathrm{PM}_{10}$, i.e., in NK3, NK7 and MR8 (Figure 3) has not been identified. The isotopic composition of Zn in $\mathrm{PM}_{10}$ in London is similar to that of $\mathrm{PM}_{2.5-80}$ collected at a high density traffic site in the same city during 2014 and 2015 , with $\delta^{66} \mathrm{Zn}_{\text {Lyon }}$ ranging between $-0.29 \%$ and $+0.17 \%$ (Figure 3). The $\delta^{66} \mathrm{Zn}_{\text {Lyon }}$ in bus air filters analysed during previous studies (Cloquet et al., 2006) overlap with the signatures in the $\mathrm{PM}_{10}$ collected at the NK and MR sites, whereas those of gasoline (Gioia et al., 2008) only overlap with three samples of $\mathrm{PM}_{10}$ out of 18 (NK3, NK7 and MR8) (Figure 3, Table S2-Sn). The relatively constant traffic densities and the similar $\mathrm{Zn} / \mathrm{Sb}$ ratios in $\mathrm{PM}_{10}$ at each sampling site (Table 2) suggest that contribution from gasoline combustion is less likely, in line with the typically low concentrations of $\mathrm{Zn}$ found in gasoline (Pignalosa et al., 2005). The light $\mathrm{Zn}$ isotope signatures found in $\mathrm{PM}_{10}$ in Barcelona $\left(\delta^{66} \mathrm{Zn}_{\text {Lyon }}=-0.83--0.45 \%\right.$ o $)$ were tentatively attributed to metallurgical emissions (Ochoa Gonzalez et al., 2016). This hypothesis agrees with previous observations pointing that industrial processes such as smelting or combustion exert an effect on the fractionation due to evaporation and/or condensation processes (Mattielli 2009; Bigalke 2010; Ochoa Gonzalez and Weiss, 2015; Thapalia et al., 2015). These findings suggest that tire wear largely contribute to $\mathrm{Zn}$ in $\mathrm{PM}_{10}$ in London, whereas for some samples the isotope signatures suggest a minor contribution from high temperature industrial 
or fossil fuel combustion.

\section{Conclusions}

The aim of this study was to determine the short-term temporal and spatial isotope variability of $\mathrm{Cu}, \mathrm{Zn}$ and $\mathrm{Pb}$ in urban $\mathrm{PM}_{10}$ collected at two sites with different traffic densities in central London, UK, and in possible sources, including non-combustion traffic emissions (tires and brakes), road furniture (road paint, manhole cover and road tarmac surface) and road dust. Samples of $\mathrm{PM}_{10}$ and possible sources were also characterized for the $\mathrm{EF}$ of other metals ( $\mathrm{Ni}, \mathrm{V}, \mathrm{Fe}, \mathrm{Sb}, \mathrm{Ba}$ and $\mathrm{Cr}$ ) to assist the source apportionment study. Copper and $\mathrm{Zn}$ concentrations and $\mathrm{EF}$ in the $\mathrm{PM}_{10}$ were higher at the sampling location with high traffic density, along with other elements commonly associated with traffic related sources including $\mathrm{Fe}, \mathrm{Sb}, \mathrm{Ba}$ and $\mathrm{Cr}$. In contrast, the $\mathrm{EF}$ of $\mathrm{Pb}$ showed no significant differences between the two sites although was enriched relative to crustal values.

The ${ }^{206} \mathrm{~Pb} /{ }^{207} \mathrm{~Pb}$ in the $\mathrm{PM}_{10}$ ranges between 1.1137 and 1.1364 , and the isotope ratios of $\mathrm{Cu}$ and $\mathrm{Zn}$ expressed as $\delta^{65} \mathrm{Cu}_{\text {NIST976 }}$ and $\delta^{66} \mathrm{Zn}_{\text {Lyon }}$ range between -0.01 and $+0.51 \%$ and between -0.21 and $+0.33 \%$, respectively. The results indicate that traffic density does not exert a significant effect on the observed isotope signatures, suggesting similar sources for these toxic metals at both sites. The $\mathrm{Pb}$ isotope signatures of the $\mathrm{PM}_{10}$ collected at the NK and MR sites overlap with those of road dust which suggests that re-suspended road dust is an important source. The similarity between the $\mathrm{Cu}$ isotope signatures in samples of $\mathrm{PM}_{10}\left(\delta^{65} \mathrm{Cu}_{\mathrm{NBS976}}\right.$ ranging between $-0.01 \pm 0.10 \%$ and $+0.51 \pm 0.10 \%$ ) and brakes $\left(\delta^{65} \mathrm{Cu}_{\mathrm{NIST} 976}\right.$ ranging between $+0.28 \pm 0.10 \%$ and $+0.63 \pm 0.14 \%$ ) , and the low $\mathrm{Cu} / \mathrm{Sb}$ ratios $(\mathrm{Cu} / \mathrm{Sb}$ ranging between 5.8 and 12) which fall within the range of $\mathrm{Cu} / \mathrm{Sb}$ found for brakes, suggest that brake wear is the dominant source of $\mathrm{Cu}$. The $\mathrm{Zn}$ isotope signatures in $\mathrm{PM}_{10}$ at $\mathrm{NK}$ and MR overlap with the signatures of tires and road dust but additional sources such as high temperature industrial emissions that impart isotopically light $\mathrm{Zn}$, need to be invoked to explain the light signatures found in 3 out of 18 samples.

\section{Acknowledgments}

We thank Barry Coles and Katharina Kreissig for assistance in the MAGIC laboratories and Stanislav Strekopytov for the analysis by ICP-MS at the Natural History Museum. Johanna Gietl is thanked for her help during sampling collection. Raquel Ochoa Gonzalez thanks the European Commission (FP7-PEOPLE-2012-IEF) for funding the project ISOTRACE (proposal 329878). We acknowledge financial support from the UK-China Scholarships for Excellence for Shuofei Dong. 


\section{References}

Abdalmogith, S.S., Harrison, R.M., 2006. An analysis of spatial and temporal properties of daily sulfate, nitrate and chloride concentrations at UK urban and rural sites. J. Environ. Monit. 8, 691-699.

Adachi, K., Tainosho, Y., 2004. Characterization of heavy metal particles embedded in tire dust. Environ. Int. 30, 1009-1017.

Amato, F., Cassee, F.R., Denier van der Gon, H.A.C., Gehrig, R., Gustafsson, M., Hafner, W., Harrison, R.M., Jozwicka, M., Kelly, F.J., Moreno, T., Prevot, A.S.H., Schaap, M., Sunyer, J., Querol, X., 2014. Urban air quality: The challenge of traffic non-exhaust emissions. Journal of Hazardous Materials 275, 31-36.

Araújo, D.F., Boaventura, G.R., Machado, W., Viers, J., Weiss, D., Patchineelam, S.R., Ruiz, I., Rodrigues, A.P.C., Babinski, M., Dantas, E., 2017. Tracing of anthropogenic zinc sources in coastal environments using stable isotope composition. Chem. Geol. 449, 226-235.

Arnold, T., Schönbächler, M., Rehkämper, M., Dong, S., Zhao, F.J., Kirk, G.J.D., Coles, B.J., Weiss, D.J., 2010. Measurement of zinc stable isotope ratios in biogeochemical matrices by double-spike MC-ICPMS and determination of the isotope ratio pool available for plants from soil. Anal. Bioanal. Chem. 398, 3115-3125.

Beddows, D.C.S., Harrison, R.M., Green, D.C., Fuller, G.W., 2015. Receptor modelling of both particle composition and size distribution from a background site in London, UK. Atmos. Chem. Phys. 15, 10107-10125.

Bigi, A., Harrison, R.M., 2010. Analysis of the air pollution climate at a central urban background site. Atmos. Environ. 44, 2004-2012.

Brewer, G.J., 2010. Copper toxicity in the general population. Clin. Neurophysiol. 121, 459-460.

Chapman, J.B., Mason, T.F.D., Weiss, D.J., Coles, B.J., Wilkinson, J.J., 2006. Chemical Separation and Isotopic Variations of $\mathrm{Cu}$ and $\mathrm{Zn}$ From Five Geological Reference Materials. Geostand. Geoanal. Res. 30, 5-16.

Cloquet, C., Carignan, J., Libourel, G., 2006. Isotopic composition of $\mathrm{Zn}$ and $\mathrm{Pb}$ atmospheric depositions in an urban/periurban area of northeastern France. Environ. Sci. Technol. 40, 6594-6600.

Cooper, J.A., Watson, J.G., 1980. Receptor Oriented Methods of Air Particulate Source Apportionment. J. Air Pollut. Control Assoc. 30, 1116-1125.

Costa, D.L., Dreher, K.L., 1997. Bioavailable transition metals in particulate matter mediate cardiopulmonary injury in healthy and compromised animal models. Environ. Health Perspect. 105, 1053-1060.

Charron, A., Harrison, R.M., 2005. Fine (PM2.5) and coarse (PM2.5-10) particulate matter on a heavily trafficked London highway: Sources and processes. Environ. Sci. Technol. 39, 7768-7776.

Chen, L.C., Lippmann, M., 2009. Effects of Metals within Ambient Air Particulate Matter (PM) on Human Health. Inhal. Toxicol. 21, 1-31.

Dong, S., Weiss, D.J., Strekopytov, S., Kreissig, K., Sun, Y., Baker, A.R., Formenti, P., 2013. Stable isotope ratio measurements of $\mathrm{Cu}$ and $\mathrm{Zn}$ in mineral dust (bulk and size fractions) from the Taklimakan Desert and the Sahel and in aerosols from the eastern tropical North Atlantic Ocean. Talanta 114, 103-109.

Flament, P., Mattielli, N., Aimoz, L., Choel, M., Deboudt, K., de Jong, J., Rimetz-Planchon, J., Weis, D., 2008. Iron isotopic fractionation in industrial emissions and urban aerosols. Chemosphere 73, 1793-1798.

Fry, C., Jarvis, K.E. and Parry, S.J., 2005. Diagnostic tool for source apportionment of heavy metals around road systems. Environment Agency Report.

Gamble, J.F., Lewis, R.J., 1996. Health and respirable particulate (PM(10)) air pollution: A causal or statistical association? Environ. Health Perspect. 104, 838-850. 
Garg, B.D., Cadle, S.H., Mulawa, P.A., Groblicki, P.J., Laroo, C., Parr, G.A., 2000. Brake wear particulate matter emissions. Environ. Sci. Technol. 34, 4463-4469.

447 Geagea, M.L., Stille, P., Gauthier-Lafaye, F., Millet, M., 2008. Tracing of industrial aerosol sources in an urban environment using $\mathrm{Pb}, \mathrm{Sr}$, and Nd isotopes. Environ. Sci. Technol. 42, 692-698.

449 Gietl, J.K., Klemm, O., 2009. Analysis of Traffic and Meteorology on Airborne Particulate Matter in Münster, Northwest 450 Germany. J. Air Waste Manage. Assoc. 59, 809-818.

451 Gietl, J.K., Lawrence, R., Thorpe, A.J., Harrison, R.M., 2010. Identification of brake wear particles and derivation of a 452 quantitative tracer for brake dust at a major road. Atmos. Environ. 44, 141-146.

453 Gioia, S., Weiss, D., Coles, B., Arnold, T., Babinski, M., 2008. Accurate and Precise Zinc Isotope Ratio Measurements in 454 Urban Aerosols. Anal. Chem. 80, 9776-9780.

455 Grigoratos, T., Martini, G., 2015. Brake wear particle emissions: a review. Environ Sci Pollut Res 22, 2491-2504.

456 Harrison, R.M., Deacon, A.R., Jones, M.R., Appleby, R.S., 1997. Sources and processes affecting concentrations of PM10 457 and PM2.5 particulate matter in Birmingham (UK). Atmos. Environ. 31, 4103-4117.

458 Hjortenkrans, D.S.T., Bergbäck, B.G., Häggerud, A.V., 2007. Metal Emissions from Brake Linings and Tires: Case Studies 459 of Stockholm, Sweden 1995/1998 and 2005. Environ. Sci. Technol. 41, 5224-5230.

460 Hüner, R., Melcher, B., Milczarek, R., Kienleitner, H., 2001. Solid lubricants with a tin sulphide and carbon base. Google 461 Patents.

462 Iijima, A., Sato, K., Yano, K., Tago, H., Kato, M., Kimura, H., Furuta, N., 2007. Particle size and composition distribution 463 analysis of automotive brake abrasion dusts for the evaluation of antimony sources of airborne particulate matter. Atmos. 464 Environ. 41, 4908-4919.

465 Jarup, L., 2003. Hazards of heavy metal contamination. British Medical Bulletin 68, 167-182.

466 John, S.G., Park, J.G., Zhan, Z.T., Boyle, E.A., 2007. The isotopic composition of some common forms of anthropogenic 467 zinc. Chem. Geol. 245, 61-69.

468 Laden, F., Neas, L.M., Dockery, D.W., Schwartz, J., 2000. Association of fine particulate matter from different sources 469 with daily mortality in six US cities. Environ. Health Perspect. 108, 941-947.

470 Lin, L., Lee, M.L., Eatough, D.J., 2010. Review of Recent Advances in Detection of Organic Markers in Fine Particulate 471 Matter and Their Use for Source Apportionment. J. Air Waste Manag. Assoc. 60, 3-25.

472 Lough, G.C., Schauer, J.J., Park, J.S., Shafer, M.M., Deminter, J.T., Weinstein, J.P., 2005. Emissions of metals associated 473 with motor vehicle roadways. Environ. Sci. Technol. 39, 826-836.

474 Majestic, B.J., Anbar, A.D., Herckes, P., 2009. Stable Isotopes as a Tool to Apportion Atmospheric Iron. Environ. Sci. 475 Technol. 43, 4327-4333.

476 Manoli, E., Voutsa, D., Samara, C., 2002. Chemical characterization and source identification/apportionment of fine and coarse air particles in Thessaloniki, Greece. Atmos. Environ. 36, 949-961. isotope study of atmospheric emissions and dry depositions within a $5 \mathrm{~km}$ radius of a $\mathrm{Pb}-\mathrm{Zn}$ refinery. Atmos. Environ. 43,

481 McKenzie, E.R., Money, J.E., Green, P.G., Young, T.M., 2009. Metals associated with stormwater-relevant brake and tire samples. Sci. Total Environ. 407, 5855-5860. Materials ERM-AE633 and ERM-AE647 for Copper and IRMM-3702 for Zinc Isotope Amount Ratio Determinations. 
Geostand. Geoanal. Research 36, 177-199.

Monna, F., Lancelot, J., Croudace, I.W., Clundy, A.B., Lewis, J.T., 1997. Pb isotopic composition of airborne particulate material from France and the southern United Kingdom: implications for Pb pollution sources in urban areas. Environ. Sci. Technol. 31, 2277-2286.

Moreno, T., Martins, V., Querol, X., Jones, T., BéruBé, K., Minguillón, M.C., Amato, F., Capdevila, M., de Miguel, E., Centelles, S., Gibbons, W., 2015. A new look at inhalable metalliferous airborne particles on rail subway platforms. Sci. Total Environ. 505, 367-375.

Moreno, T., Perez, N., Querol, X., Amato, F., Alastuey, A., Bhatia, R., Spiro, B., Hanvey, M., Gibbons, W., 2010. Physicochemical variations in atmospheric aerosols recorded at sea onboard the Atlantic-Mediterranean 2008 Scholar Ship cruise (Part II): Natural versus anthropogenic influences revealed by PM10 trace element geochemistry. Atmos. Environ. 44, 2563-2576.

Noble, S.R., Horstwood, M.S.A., Davy, P., Pashley, V., Spiro, B., Smith, S., 2008. Evolving Pb isotope signatures of London airborne particulate matter (PM10) - constraints from on-filter and solution-mode MC-ICP-MS. J. Environ. Monit. $10,830-836$.

Nriagu, J.O., Pacyna, J.M., 1988. Quantitative assessment of worldwide contamination of air, water, and soils by trace metals. Nature 333, 134-139.

Ochoa Gonzalez, R., Strekopytov, S., Amato, F., Querol, X., Reche, C., Weiss, D., 2016. New Insights from Zinc and Copper Isotopic Compositions into the Sources of Atmospheric Particulate Matter from Two Major European Cities. Environ. Sci. Technol. 50, 9816-9824.

Ochoa Gonzalez, R., Weiss, D., 2015. Zinc Isotope Variability in Three Coal-Fired Power Plants: A Predictive Model for Determining Isotopic Fractionation during Combustion. Environ. Sci. Technol. 49, 12560-12567.

Ozkaynak, H., Xue, J., Spengler, J., Wallace, L., Pellizzari, E., Jenkins, P., 1996. Personal exposure to airborne particles and metals: Results from the particle team study in Riverside, California. J. Expo. Anal. Env. Epid. 6, 57-78.

Peel, K., Weiss, D., Chapman, J., Arnold, T., Coles, B., 2008. A simple combined sample-standard bracketing and inter-element correction procedure for accurate mass bias correction and precise $\mathrm{Zn}$ and $\mathrm{Cu}$ isotope ratio measurements. J. Anal. At. Spectrom. 23, 103-110.

Peltier, R.E., Lippmann, M., 2010. Residual oil combustion: 2. Distributions of airborne nickel and vanadium within New York City. J. Expo. Sci. Env. Epid. 20, 342-350.

Pignalosa, G., Knochen, M., Cabrera, N., 2005. Determination of Zinc-Based Additives in Lubricating Oils by Flow-Injection Analysis with Flame-AAS Detection Exploiting Injection with a Computer-Controlled Syringe. J. Autom. Method. Manag. 1, 1-7.

Polissar, A.V., Hopke, P.K., Poirot, R.L., 2001. Atmospheric aerosol over Vermont: Chemical composition and sources. Environ. Sci. Technol. 35, 4604-4621.

Prasad, A.S., Bao, B., Beck, F.W.J., Kucuk, O., Sarkar, F.H., 2004. Antioxidant effect of zinc in humans. Free Radical Bio. Med. 37, 1182-1190.

Querol, X., Alastuey, A., Rodriguez, S., Plana, F., Ruiz, C.R., Cots, N., Massague, G., Puig, O., 2001. PM10 and PM2.5 source apportionment in the Barcelona Metropolitan area, Catalonia, Spain. Atmos. Environ. 35, 6407-6419.

Rodriguez, S., Querol, X., Alastuey, A., Viana, M.M., Alarcon, M., Mantilla, E., Ruiz, C.R., 2004. Comparative PM10-PM2.5 source contribution study at rural, urban and industrial sites during PM episodes in Eastern Spain. Sci. Total Environ. 328, 95-113. 
Salma, I., Maenhaut, W., 2006. Changes in elemental composition and mass of atmospheric aerosol pollution between 1996 and 2002 in a Central European city. Environ. Pollution 143, 479-488.

Samek, L., Stegowski, Z., Furman, L., 2016. Preliminary PM2.5 and PM10 fractions source apportionment complemented by statistical accuracy determination. Nukleonika $61,75-83$.

Sivry, Y., Riotte, J., Sonke, J.E., Audry, S., Schäfer, J., Viers, J., Blanc, G., Freydier, R., Dupré, B., 2008. Zn isotopes as tracers of anthropogenic pollution from Zn-ore smelters The Riou Mort-Lot River system. Chem. Geol. 255, $295-304$.

Straffelini, G., Ciudin, R., Ciotti, A., Gialanella, S., 2015. Present knowledge and perspectives on the role of copper in brake materials and related environmental issues: A critical assessment. Environ. Pollution 207, 211-219.

Thorpe, A.J., Harrison, R.M., Boulter, P.G., McCrae, I.S., 2007. Estimation of particle resuspension source strength on a major London Road. Atm. Environ. 41, 8007-8020.

Thorpe, A., Harrison, R.M., 2008. Sources and properties of non-exhaust particulate matter from road traffic: A review. Sci. Total Environ. 400, 270-282.

Thurston, G.D., Spengler, J.D., 1985. A quantitative assessment of source contributions to inhalable particulate matter pollution in metropolitan Boston. Atm. Environ. (1967) 19, 9-25.

Tong, S., von Schirnding, Y.E., Prapamontol, T., 2000. Environmental lead exposure: a public health problem of global dimensions. B. World Health Organ. 78, 1068-1077.

Visser, S., Slowik, J.G., Furger, M., Zotter, P., Bukowiecki, N., Dressler, R., Flechsig, U., Appel, K., Green, D.C., Tremper, A.H., Young, D.E., Williams, P.I., Allan, J.D., Herndon, S.C., Williams, L.R., Mohr, C., Xu, L., Ng, N.L., Detournay, A., Barlow, J.F., Halios, C.H., Fleming, Z.L., Baltensperger, U., Prévôt, A.S.H., 2015. Kerb and urban increment of highly time-resolved trace elements in PM10, PM2.5 and PM1.0 winter aerosol in London during ClearfLo 2012. Atmos. Chem. Phys. 15, 2367-2386.

Wåhlin, P., Berkowicz, R., Palmgren, F., 2006. Characterisation of traffic-generated particulate matter in Copenhagen. Atm. Environ. 40, 2151-2159.

Walsh, C.T., Sandstead, H.H., Prasad, A.S., Newberne, P.M., Fraker, P.J., 1994. Zinc: health effects and research priorities for the 1990s. Environ. Health Persp. 102, 5-46.

Weckwerth, G., 2001. Verification of traffic emitted aerosol components in the ambient air of Cologne (Germany). Atmos. Environ. 35, 5525-5536.

Wedepohl, K.H., 1995. The composition of the continental crust. Geochim. Cosmochim. Acta 59, 1217-1232.

Weiss, D.J., Kober, B., Dalgopolova, A., Gallagher, K., Spiro, B., Le Roux, G., Mason, T.F.D., Kylander, M., Coles, B.J., 2004. Accurate and precise $\mathrm{Pb}$ isotope ratio measurements in environmental samples by MC-ICP-MS. Int. J. Mass Spectrom. 232, 205-215.

Weiss, D.J., Rehkdmper, M., Schoenberg, R., McLaughlin, M., Kirby, J., Campbell, P.G.C., Arnold, T., Chapman, J., Peel, K., Gioia S., 2008. Application of Nontraditional Stable-Isotope Systems to the Study of Sources and Fate of Metals in the Environment. Environ. Sci. Technol. 42, 655-664.

Widory, D., Liu, X.D., Dong, S.P., 2010. Isotopes as tracers of sources of lead and strontium in aerosols (TSP \& PM2.5) in Beijing. Atmos. Environ. 44, 3679-3687.

Wiederhold J.G., 2015. Metal Stable Isotope Signatures as Tracers in Environmental Geochemistry. Environ. Sci. Technol. 49, 2606-2624. 


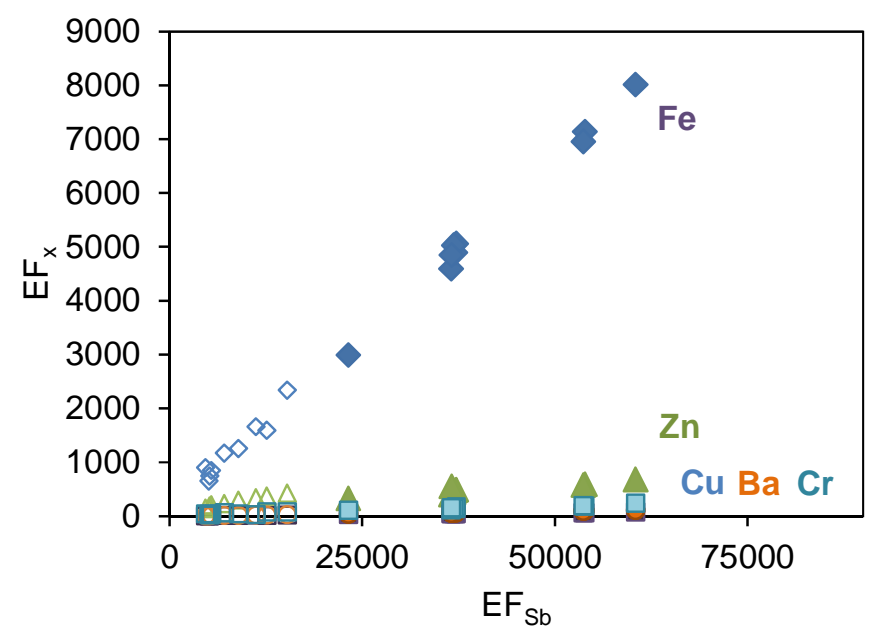

Figure 1. Relationship between the enrichment factors of $\mathrm{Sb}\left(\mathrm{EF}_{\mathrm{Sb}}\right)$ and $\mathrm{EF}_{\mathrm{Fe}}\left(\mathrm{R}^{2}=0.9960\right), \mathrm{EF}_{\mathrm{Cu}}$ $\left(R^{2}=0.9972\right), E_{Z n}\left(R^{2}=0.8686\right), E_{B a}\left(R^{2}=0.9949\right)$ and $E_{C r}\left(R^{2}=0.9385\right)$ in the $\mathrm{PM}_{10}$ collected in North Kensington (open symbols) and Marylebone Road (closed symbols). 

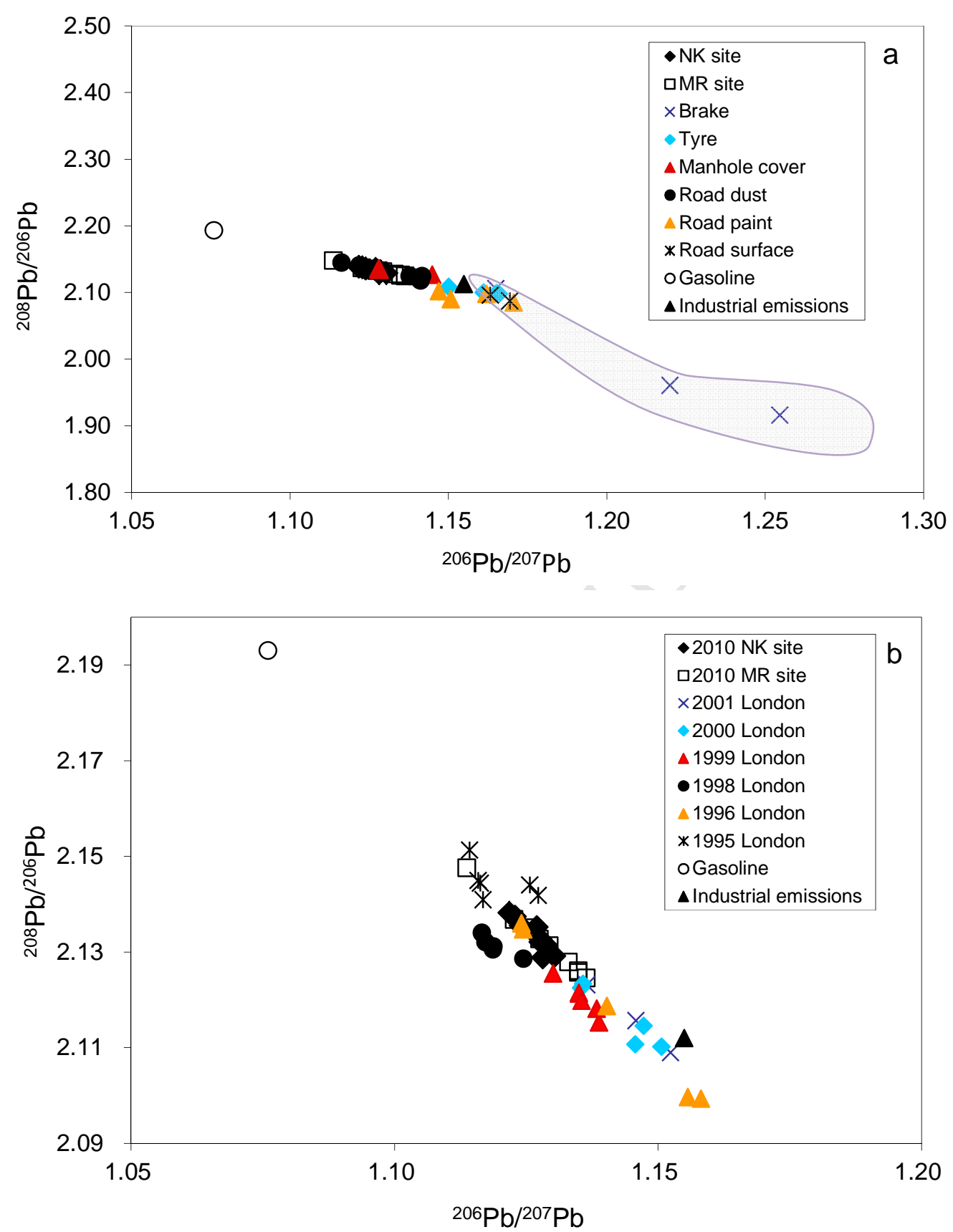

Figure 2. (a) ${ }^{208} \mathrm{~Pb} /{ }^{206} \mathrm{~Pb}$ versus ${ }^{206} \mathrm{~Pb} /{ }^{207} \mathrm{~Pb}$ plot of the $\mathrm{PM}_{10}$ samples collected in Marylebone (MR site) and North Kensington (NK site) and possible sources in this study; (b) ${ }^{208} \mathrm{~Pb} /{ }^{206} \mathrm{~Pb}$ versus ${ }^{206} \mathrm{~Pb} /{ }^{207} \mathrm{~Pb}$ plot of the $\mathrm{PM}_{10}$ measured in London since the phasing out of leaded gasoline between 1996 and 2001, as well as gasoline and industrial emissions (Noble et al., 2008 and Monna et al., 1997) and during 2010 (this study). 2SD are not displayed in the figure as they are small and fall within the marker dimensions. 

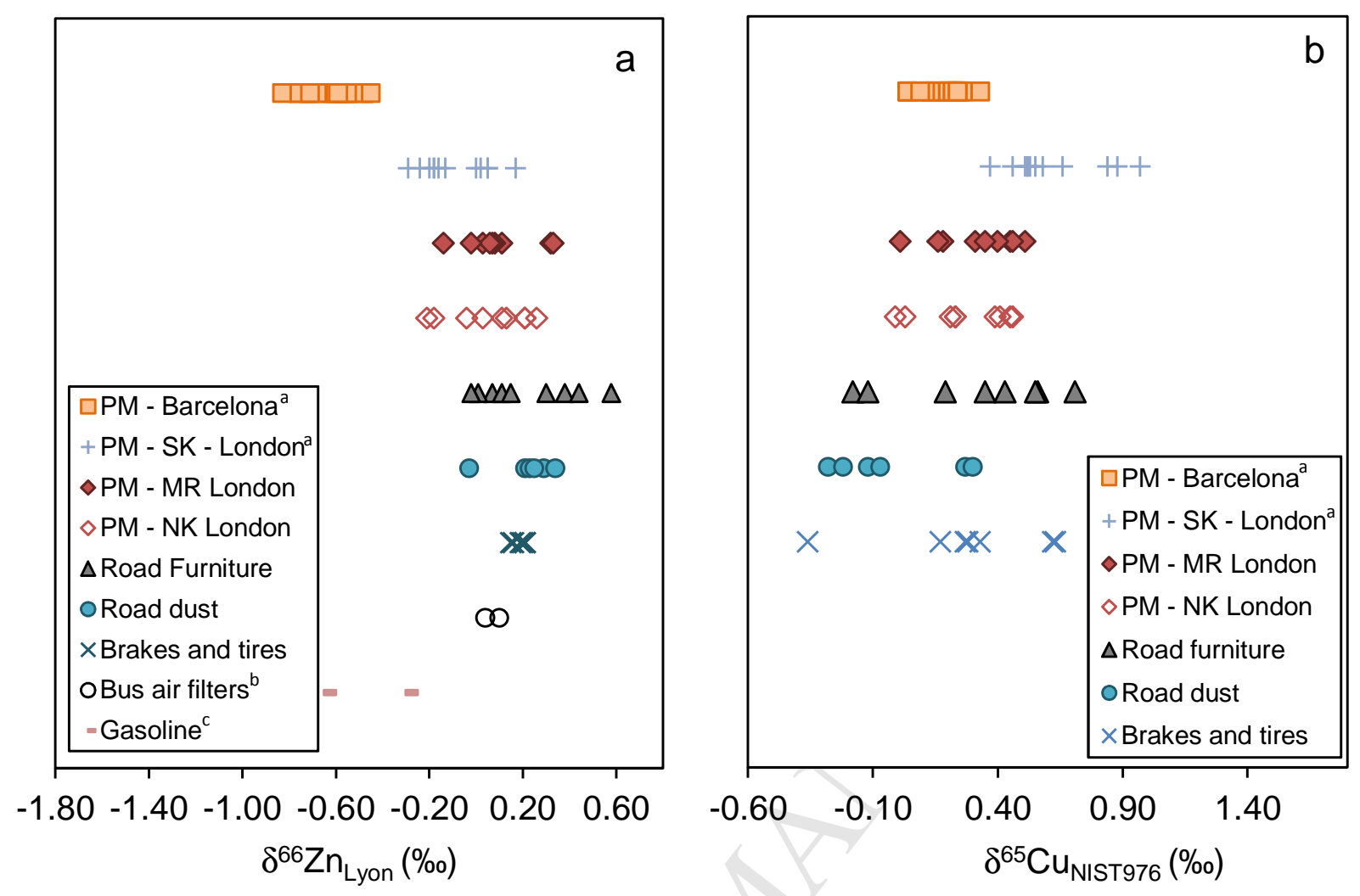

Figure 3. Zinc (a) and $\mathrm{Cu}$ (b) isotopic composition in $\mathrm{PM}_{10}$ collected at the NK site (PM-NK London) and the MR site (PM-MR London) and local sources during this study (summer 2010). Average 2SD for $\mathrm{Zn}$ and $\mathrm{Cu}$ isotope measurements are 0.08 and $0.10 \%$ o, respectively. Also shown are previous published $\mathrm{Zn}$ and $\mathrm{Cu}$ isotope signatures in atmospheric $\mathrm{PM}_{2.5-80}$ collected in South Kensington in London during 18 months between 2014 and 2015 (PM - SK - London), and $\mathrm{PM}_{10}$ collected in Barcelona during two sampling campaigns in 2012 and 2013 labelled as PM - Barcelona (Ochoa Gonzalez et al., 2016) ${ }^{\mathrm{a}}$ with average $2 \mathrm{SD}$ for $\mathrm{Zn}$ and $\mathrm{Cu}$ isotope ratios of 0.08 and $0.11 \%$, respectively. The $\mathrm{Zn}$ isotope composition of gasoline (Gioia et al., 2008) ${ }^{\mathrm{b}}$ and that from exhaust emissions represented by previously analyzed bus air filters (Cloquet et al., 2006) ${ }^{\mathrm{c}}$ are also shown. The $\mathrm{Cu}$ isotope signatures in PM collected during the winter season in London (PM - SK - London) are highlighted as they shown heavier values, explained by an increasing fossil fuel combustion. Previously published $\mathrm{Zn}$ isotope ratios referring to the IRMM-3702 standard were recalculated to JMC 3-0749L Lyon using an isotopic offset of $+0.32 \%$ o for $\mathrm{Zn}$ (Moeller et al., 2012). 


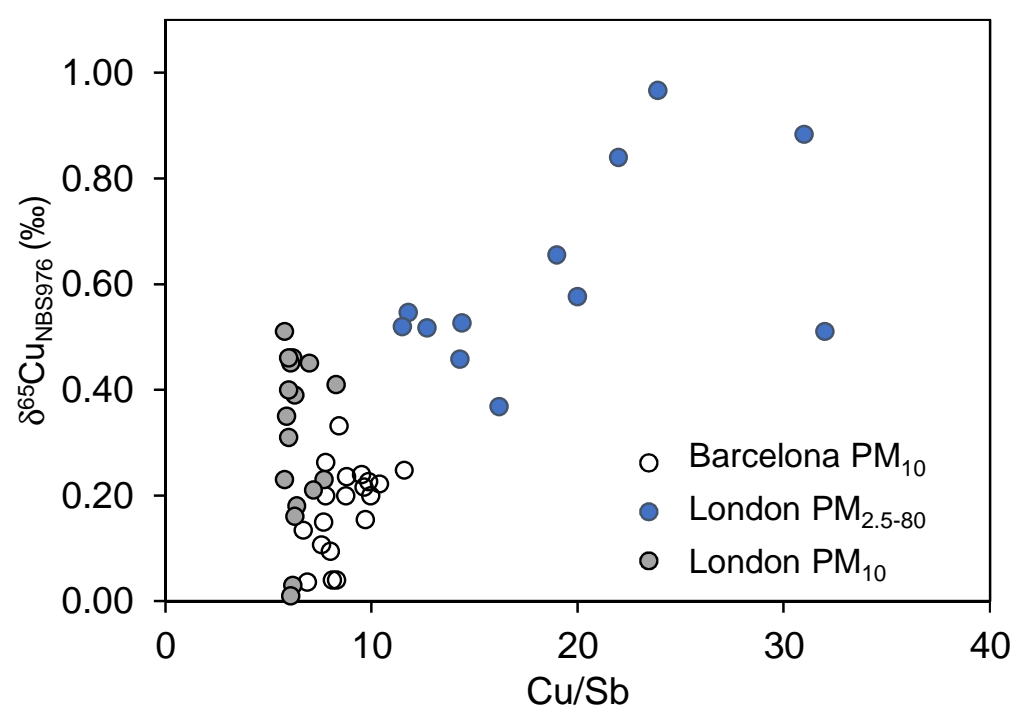

Figure 4. Relationship between $\mathrm{Cu} / \mathrm{Sb}$ ratios and $\delta^{65} \mathrm{Cu}_{\mathrm{NIST} 976}$ in $\mathrm{PM}_{10}$ collected at the $\mathrm{NK}$ site and the MR site in this study (London $\mathrm{PM}_{10}$ ), and previous publish data in $\mathrm{PM}_{2.5-80}$ from London (London $\mathrm{PM}_{2.5-80}$ ) and in $\mathrm{PM}_{10}$ from Barcelona (Ochoa Gonzalez et al., 2016). 
1 Table 1. Concentrations of $\mathrm{PM}_{10}$, major and trace elements in the $\mathrm{PM}_{10}$ samples collected in Marylebone (MR) and North Kensington (NK), 2 and $\mathrm{Cu} / \mathrm{Sb}$ ratios.

\begin{tabular}{|c|c|c|c|c|c|c|c|c|c|c|c|c|c|}
\hline \multirow[b]{2}{*}{ Sample } & \multirow[b]{2}{*}{ Reference } & \multicolumn{11}{|c|}{ Concentrations } & \multirow[b]{2}{*}{$\mathrm{Cu} / \mathrm{Sb}$} \\
\hline & & $\begin{array}{c}\mathrm{PM}_{10} \\
\left(\mu \mathrm{g} \mathrm{m}^{-3}\right)\end{array}$ & $\begin{array}{c}\mathrm{Fe} \\
\left(\mathrm{ng} \mathrm{m}^{-3}\right)\end{array}$ & $\begin{array}{c}\mathrm{Al} \\
\left(\mathrm{ng} \mathrm{m}^{-3}\right)\end{array}$ & $\begin{array}{c}\mathrm{Cu} \\
\left(\mathrm{ng} \mathrm{m}^{-3}\right)\end{array}$ & $\begin{array}{c}\mathrm{Zn} \\
\left(\mathrm{ng} \mathrm{m}^{-3}\right)\end{array}$ & $\begin{array}{c}\mathrm{Sb} \\
\left(\mathrm{ng} \mathrm{m}^{-3}\right)\end{array}$ & $\begin{array}{r}\mathrm{Ba} \\
\left(\mathrm{ng} \mathrm{m}^{-3}\right)\end{array}$ & $\begin{array}{c}\mathrm{Pb} \\
\left(\mathrm{ng} \mathrm{m}^{-3}\right)\end{array}$ & $\begin{array}{c}\mathrm{Cr} \\
\left(\mathrm{ng} \mathrm{m}^{-3}\right)\end{array}$ & $\begin{array}{c}\mathrm{Ni} \\
\left(\mathrm{ng} \mathrm{m}^{-3}\right)\end{array}$ & $\begin{array}{c}\mathrm{V} \\
\left(\mathrm{ng} \mathrm{m}^{-3}\right)\end{array}$ & \\
\hline \multirow[t]{10}{*}{$\mathrm{NK}-\mathrm{PM}_{10}$} & NK1 & 12 & 79 & 23 & 3.1 & 2.9 & 0.5 & 2.0 & 1.3 & 0.2 & 0.5 & 0.7 & 6.2 \\
\hline & NK2 & 12 & 46 & 14 & 2.3 & 1.4 & 0.3 & 1.1 & 0.6 & 0.3 & 0.4 & 0.5 & 7.7 \\
\hline & NK3 & 10 & 66 & 13 & 3.1 & 2.7 & 0.5 & 1.7 & 1.3 & 0.2 & 0.2 & 0.3 & 6.2 \\
\hline & NK4 & 17 & 58 & 12 & 2.5 & 1.8 & 0.3 & 1.6 & 0.8 & 0.4 & 0.3 & 0.4 & 8.3 \\
\hline & NK5 & 15 & 46 & 6.1 & 1.9 & 1.4 & 0.3 & 1.2 & 0.7 & 0.1 & 0.2 & 0.2 & 6.3 \\
\hline & NK6 & 17 & 89 & 22 & 3.5 & 3.1 & 0.5 & 2.0 & 1.1 & 0.3 & 0.4 & 0.6 & 7.0 \\
\hline & NK7 & 15 & 68 & 8.2 & 3.6 & 2.3 & 0.5 & 1.9 & 0.9 & 0.3 & 0.2 & 0.2 & 7.2 \\
\hline & NK8 & 12 & 58 & 8.6 & 2.5 & 2.2 & 0.4 & 1.5 & 1.2 & 0.3 & 0.2 & 0.1 & 6.3 \\
\hline & NK9 & 14 & 87 & 29 & 3.5 & 2.8 & 0.6 & 1.8 & 1.4 & 0.4 & 0.2 & 0.1 & 5.8 \\
\hline & Average $\pm \mathrm{SD}$ & $14 \pm 3$ & $66 \pm 16$ & $15 \pm 8$ & $2.9 \pm 0.6$ & $2.3 \pm 0.6$ & $0.4 \pm 0.1$ & $1.6 \pm 0.4$ & $1.0 \pm 0.3$ & $0.3 \pm 0.1$ & $0.3 \pm 0.1$ & $0.3 \pm 0.2$ & $6.8 \pm 0.9$ \\
\hline \multirow[t]{10}{*}{$\mathrm{MR}-\mathrm{PM}_{10}$} & MR1 & 37 & 2660 & 150 & 130 & 41 & 22 & 84 & 8.8 & 8.2 & 3.6 & 2.6 & 5.8 \\
\hline & MR2 & 28 & 550 & 20 & 26 & 8.0 & 4.3 & 18 & 1.1 & 1.7 & 0.7 & 0.6 & 6.1 \\
\hline & MR3 & 29 & 436 & 24 & 21 & 7.8 & 3.5 & 14 & 1.9 & 1.5 & 0.6 & 0.4 & 6.1 \\
\hline & MR4 & 38 & 481 & 25 & 24 & 8.4 & 3.7 & 15 & 1.4 & 1.9 & 0.9 & 0.4 & 6.4 \\
\hline & MR5 & 29 & 494 & 16 & 24 & 7.3 & 3.9 & 16 & 1.3 & 1.7 & 0.7 & 0.3 & 6.0 \\
\hline & MR6 & 41 & 641 & 35 & 33 & 11 & 5.2 & 20 & 1.8 & 2.5 & 1.0 & 0.8 & 6.3 \\
\hline & MR7 & 34 & 2300 & 89 & 110 & 35 & 19 & 72 & 6.8 & 7.8 & 2.7 & 1.5 & 6.0 \\
\hline & MR8 & 27 & 279 & 15 & 13 & 5.5 & 2.2 & 7.9 & 1.7 & 1.1 & 0.3 & 0.2 & 6.0 \\
\hline & MR9 & 18 & 212 & 17 & 9.4 & 3.7 & 1.6 & 5.7 & 1.2 & 0.9 & 0.3 & 0.1 & 5.9 \\
\hline & Average $\pm \mathrm{SD}$ & $31 \pm 7$ & - & - & - & - & - & - & - & - & - & - & $6.1 \pm 0.2$ \\
\hline
\end{tabular}


5 Table 2. Concentrations of major and trace elements in local sources close to Marylebone (MR) and North Kensington (NK), including $6 \mathrm{Cu} / \mathrm{Sb}$ ratios. '<' means below detection limit; '-' means not calculated.

7

\begin{tabular}{|c|c|c|c|c|c|c|c|c|c|c|c|c|}
\hline \multirow[b]{2}{*}{ Sample } & \multirow[b]{2}{*}{ Reference } & \multicolumn{10}{|c|}{ Concentrations } & \multirow[b]{2}{*}{$\mathrm{Cu} / \mathrm{Sb}$} \\
\hline & & $\begin{array}{c}\mathrm{Fe} \\
\left(\mathrm{mg} \mathrm{g}^{-1}\right)\end{array}$ & $\begin{array}{c}\mathrm{Al} \\
\left(\mathrm{mg} \mathrm{g}^{-1}\right)\end{array}$ & $\begin{array}{c}\mathrm{Cu} \\
\left(\mu \mathrm{g} \mathrm{g}^{-1}\right)\end{array}$ & $\begin{array}{c}\mathrm{Zn} \\
\left(\mu \mathrm{g} \mathrm{g}^{-1}\right)\end{array}$ & $\begin{array}{c}\mathrm{Sb} \\
\left(\mu \mathrm{g} \mathrm{g}^{-1}\right)\end{array}$ & $\begin{array}{c}\mathrm{Ba} \\
\left(\mu \mathrm{g} \mathrm{g}^{-1}\right)\end{array}$ & $\begin{array}{c}\mathrm{Pb} \\
\left(\mu \mathrm{g} \mathrm{g}^{-1}\right)\end{array}$ & $\begin{array}{c}\mathrm{Cr} \\
\left(\mu \mathrm{g} \mathrm{g}^{-1}\right)\end{array}$ & $\begin{array}{c}\mathrm{Ni} \\
\left(\mu \mathrm{g} \mathrm{g}^{-1}\right)\end{array}$ & $\begin{array}{c}\mathrm{V} \\
\left(\mu \mathrm{g} \mathrm{g}^{-1}\right)\end{array}$ & \\
\hline \multirow[t]{3}{*}{ Brake } & FSB-1 & 6.8 & 9.5 & 6.1 & 20 & 0.2 & 1000 & 5.3 & 89 & 51 & 9.7 & 27 \\
\hline & FSB-2 & 5.2 & 7.1 & 4.4 & 17 & 0.1 & 1300 & 4.0 & 80 & 41 & 7.0 & 39 \\
\hline & HBP-1 & 89 & 5.5 & 25 & 46 & 0.8 & 310 & 38 & 110 & 28 & 15 & 30 \\
\hline \multirow[t]{3}{*}{ Tire } & R43/54-1 & 0.4 & 0.2 & 43 & 8100 & $<$ & 12 & 9.9 & $<$ & $<$ & $<$ & - \\
\hline & R43/54-2 & 0.3 & 0.3 & 41 & 13000 & $<$ & 19 & 14 & $<$ & 1.4 & $<$ & - \\
\hline & R56/57-1 & 0.2 & 0.4 & 26 & 7400 & $<$ & 2.1 & 9.1 & $<$ & $<$ & $<$ & - \\
\hline \multirow[t]{4}{*}{ Manhole cover } & NKMHC-1 & 68 & 5.7 & 52 & 370 & 7.4 & 550 & 690 & 130 & 100 & 26 & 7.0 \\
\hline & NKMHC-2 & 25 & 2.8 & 20 & 130 & 3.6 & 1100 & 56 & 93 & 86 & 15 & 5.4 \\
\hline & MRMHC-1 & 52 & 5.2 & 170 & 530 & 17 & 120 & 210 & 2300 & 1700 & 76 & 9.9 \\
\hline & MRMHC-2 & 43 & 1.5 & 89 & 420 & 7.5 & 120 & 89 & 120 & 110 & 120 & 12 \\
\hline \multirow[t]{6}{*}{ Road dust } & NKRD-1 & 9.4 & 4.4 & 70 & 220 & 3.3 & 93 & 140 & 29 & 11 & 19 & 21 \\
\hline & NKRD-2 & 7.6 & 3.2 & 17 & 80 & 1.0 & 34 & 22 & 29 & 100 & 15 & 17 \\
\hline & NKRD-3 & 18 & 13 & 25 & 170 & 0.7 & 86 & 26 & 31 & 18 & 56 & 35 \\
\hline & MRRD-1 & 17 & 6.0 & 800 & 560 & 21 & 160 & 410 & 55 & 26 & 23 & 38 \\
\hline & MRRD-2 & 14 & 3.7 & 74 & 350 & 10 & 97 & 170 & 54 & 13 & 15 & 7.3 \\
\hline & MRRD-3 & 10 & 4.0 & 140 & 350 & 40 & 94 & 54 & 40 & 17 & 14 & 3.5 \\
\hline \multirow[t]{4}{*}{ Road paint } & NKRP-1 & 0.6 & 0.3 & 1.8 & 44 & $<$ & 2.4 & 2.8 & 3.2 & 4.0 & 0.5 & - \\
\hline & NKRP-2 & 0.4 & 0.2 & $<$ & 4.8 & 93 & 200 & 3100 & 840 & 3.4 & 0.7 & - \\
\hline & MRRP-1 & 0.7 & 0.3 & 4.3 & 14 & 0.5 & 6.1 & 3.8 & 1.1 & 2.4 & 0.7 & 8.6 \\
\hline & MRRP-2 & 1.3 & 2.4 & 2.6 & 14 & $<$ & 5.4 & 2.9 & 1.3 & 6.6 & 1.9 & - \\
\hline \multirow{2}{*}{$\begin{array}{l}\text { Road tarmac } \\
\text { surface }\end{array}$} & NKRS-1 & 8.2 & 4.9 & 7.1 & 40 & 0.4 & 64 & 11 & 16 & 15 & 28 & 18 \\
\hline & NKRS-2 & 7.3 & 4.4 & 5.2 & 34 & 0.3 & 100 & 8.8 & 20 & 19 & 21 & 17 \\
\hline
\end{tabular}


10 Table 3. Enrichment factors (EFs) in local sources and the $\mathrm{PM}_{10}$ samples collected at Marylebone

11 (MR) and North Kensington (NK) sites. '-' means not calculated.

\begin{tabular}{|c|c|c|c|c|c|c|c|c|c|c|}
\hline \multirow{2}{*}{ Sample } & \multirow{2}{*}{ Reference } & \multicolumn{9}{|c|}{ EFs } \\
\hline & & $\mathrm{Fe}$ & $\mathrm{Cu}$ & $\mathrm{Zn}$ & $\mathrm{Sb}$ & $\mathrm{Ba}$ & $\mathrm{Pb}$ & $\mathrm{Cr}$ & $\mathrm{Ni}$ & $\mathrm{V}$ \\
\hline \multirow[t]{10}{*}{$\mathrm{NK}-\mathrm{PM}_{10}$} & NK1 & 8.7 & 740 & 190 & 5300 & 10 & 258 & 18 & 83 & 44 \\
\hline & NK2 & 8.2 & 900 & 150 & 4700 & 9.0 & 199 & 47 & 110 & 54 \\
\hline & NK3 & 12 & 1300 & 300 & 9000 & 15 & 458 & 41 & 68 & 31 \\
\hline & NK4 & 13 & 1200 & 230 & 7100 & 16 & 317 & 67 & 100 & 45 \\
\hline & NK5 & 19 & 1700 & 340 & 11000 & 22 & 485 & 26 & 110 & 55 \\
\hline & NK6 & 10 & 850 & 210 & 5500 & 11 & 220 & 33 & 72 & 36 \\
\hline & NK7 & 21 & 2300 & 430 & 15000 & 27 & 484 & 81 & 95 & 37 \\
\hline & NK8 & 17 & 1600 & 380 & 13000 & 20 & 663 & 80 & 100 & 25 \\
\hline & NK9 & 7.6 & 650 & 150 & 5200 & 7.3 & 225 & 34 & 28 & 7.0 \\
\hline & Average \pm SD & $13 \pm 5$ & $1200 \pm 600$ & $300 \pm 200$ & $8000 \pm 4000$ & $15 \pm 7$ & $400 \pm 200$ & $50 \pm 30$ & $90 \pm 30$ & $40 \pm 20$ \\
\hline \multirow[t]{10}{*}{$\mathrm{MR}-\mathrm{PM}_{10}$} & MR1 & 45 & 4600 & 410 & 37000 & 65 & 270 & 120 & 100 & 25 \\
\hline & MR2 & 69 & 7100 & 600 & 54000 & 100 & 245 & 190 & 150 & 44 \\
\hline & MR3 & 46 & 4900 & 490 & 37000 & 66 & 362 & 140 & 110 & 22 \\
\hline & MR4 & 48 & 5100 & 490 & 37000 & 69 & 247 & 170 & 150 & 25 \\
\hline & MR5 & 78 & 8000 & 680 & 61000 & 110 & 366 & 240 & 180 & 31 \\
\hline & MR6 & 46 & 5000 & 450 & 37000 & 66 & 232 & 160 & 120 & 31 \\
\hline & MR7 & 65 & 7000 & 580 & 54000 & 93 & 348 & 190 & 130 & 25 \\
\hline & MR8 & 47 & 4800 & 560 & 37000 & 62 & 518 & 160 & 93 & 19 \\
\hline & MR9 & 31 & 3000 & 330 & 23000 & 39 & 334 & 120 & 64 & 13 \\
\hline & Average \pm SD & $50 \pm 20$ & $6000 \pm 2000$ & $500 \pm 200$ & $40000 \pm 20000$ & $70 \pm 30$ & $330 \pm 90$ & $170 \pm 40$ & $130 \pm 40$ & $26 \pm 9$ \\
\hline \multirow[t]{3}{*}{ Brake } & FSB-1 & 1.8 & 3.5 & 3.2 & 5.9 & 13 & 2.6 & 21 & 22 & 1.5 \\
\hline & FSB-2 & 1.9 & 3.3 & 3.5 & 3.9 & 21 & 2.6 & 25 & 24 & 1.4 \\
\hline & HBP-1 & 41 & 25 & 13 & 37 & 6.6 & 32 & 46 & 21 & 3.9 \\
\hline \multirow[t]{3}{*}{ Tire } & $\mathrm{R} 43 / 54-1$ & 4.6 & 1200 & 60000 & - & 6.9 & 230 & - & - & - \\
\hline & R43/54-2 & 2.6 & 780 & 69000 & - & 7.5 & 220 & - & 21 & - \\
\hline & R56/57-1 & 1.5 & 400 & 31000 & - & 0.7 & 110 & - & - & - \\
\hline Manhole & NKMHC-1 & 30 & 49 & 97 & 330 & 11 & 550 & 50 & 75 & 6.6 \\
\hline \multirow[t]{3}{*}{ cover } & NKMHC-2 & 23 & 38 & 72 & 320 & 44 & 92 & 74 & 130 & 8.1 \\
\hline & MRMHC-1 & 25 & 170 & 150 & 800 & 2.7 & 180 & 970 & 1400 & 21 \\
\hline & MRMHC-2 & 73 & 330 & 420 & 1300 & 9.1 & 280 & 190 & 310 & 120 \\
\hline \multirow[t]{6}{*}{ Road dust } & NKRD-1 & 5.3 & 85 & 73 & 190 & 2.4 & 140 & 14 & 10 & 6.3 \\
\hline & NKRD-2 & 6.0 & 29 & 37 & 79 & 1.2 & 32 & 20 & 131 & 6.8 \\
\hline & NKRD-3 & 3.6 & 10 & 19 & 14 & 0.8 & 9.0 & 5.2 & 5.8 & 6.4 \\
\hline & MRRD-1 & 7 & 730 & 140 & 880 & 3.2 & 300 & 21 & 18 & 5.7 \\
\hline & MRRD-2 & 9.5 & 110 & 140 & 680 & 3.0 & 200 & 32 & 14 & 5.9 \\
\hline & MRRD-3 & 6.3 & 190 & 130 & 2500 & 2.7 & 62 & 22 & 17 & 5.3 \\
\hline \multirow[t]{4}{*}{ Road paint } & NKRP-1 & 4.6 & 28 & 190 & - & 0.8 & 37 & 21 & 48 & 2.2 \\
\hline & NKRP-2 & 5.1 & - & 39 & 130000 & 120 & 76000 & 10000 & 76 & 5.4 \\
\hline & MRRP-1 & 7.0 & 88 & 80 & 450 & 2.7 & 67 & 9.6 & 39 & 3.9 \\
\hline & MRRP-2 & 1.4 & 5.8 & 8.5 & - & 0.3 & 5.5 & 1.2 & 11 & 1.1 \\
\hline Road & NKRS-1 & 4.2 & 7.9 & 12 & 22 & 1.5 & 11 & 7.3 & 13 & 8.3 \\
\hline surface & NKRS-2 & 4.2 & 6.4 & 12 & 18 & 2.8 & 9.2 & 10 & 18 & 7.1 \\
\hline
\end{tabular}


12 Table 4. Lead isotope ratios of $\mathrm{PM}_{10}$ samples collected at Marylebone Road (MR) and North

13 Kensington (NK) and sources analyzed during this study. Each sample has been measured 3 or 4

14 times to calculate the 2SD.

\begin{tabular}{|c|c|c|c|c|c|c|c|}
\hline \multirow{2}{*}{ Sample } & \multirow{2}{*}{ Sample ID } & \multicolumn{6}{|c|}{$\mathrm{Pb}$ isotope ratios } \\
\hline & & ${ }^{206} \mathrm{~Pb} /{ }^{204} \mathrm{~Pb}$ & 2SD & ${ }^{206} \mathrm{~Pb} /{ }^{207} \mathrm{~Pb}$ & $2 \mathrm{SD}$ & ${ }^{208} \mathrm{~Pb} /{ }^{206} \mathrm{~Pb}$ & $2 \mathrm{SD}$ \\
\hline \multirow[t]{9}{*}{$\mathrm{NK}-\mathrm{PM}_{10}$} & NK1 & 17.446 & 0.004 & 1.1218 & 0.0001 & 2.1382 & 0.0002 \\
\hline & NK2 & 17.552 & 0.003 & 1.1277 & 0.0001 & 2.1327 & 0.0002 \\
\hline & NK3 & 17.465 & 0.005 & 1.1229 & 0.0001 & 2.1374 & 0.0002 \\
\hline & NK4 & 17.537 & 0.002 & 1.1270 & 0.0001 & 2.1352 & 0.0001 \\
\hline & NK5 & 17.554 & 0.003 & 1.1277 & 0.0001 & 2.1321 & 0.0001 \\
\hline & NK6 & 17.569 & 0.004 & 1.1287 & 0.0001 & 2.1315 & 0.0001 \\
\hline & NK7 & 17.598 & 0.004 & 1.1304 & 0.0001 & 2.1291 & 0.0001 \\
\hline & NK8 & 17.487 & 0.004 & 1.1239 & 0.0001 & 2.1355 & 0.0001 \\
\hline & NK9 & 17.564 & 0.003 & 1.1282 & 0.0001 & 2.1288 & 0.0001 \\
\hline \multirow[t]{9}{*}{$\mathrm{MR}-\mathrm{PM}_{10}$} & MR1 & 17.512 & 0.002 & 1.1256 & 0.0001 & 2.1351 & 0.0001 \\
\hline & MR2 & 17.643 & 0.005 & 1.1330 & 0.0001 & 2.1279 & 0.0001 \\
\hline & MR3 & 17.581 & 0.005 & 1.1294 & 0.0001 & 2.1313 & 0.0002 \\
\hline & MR4 & 17.677 & 0.003 & 1.1349 & 0.0001 & 2.1261 & 0.0001 \\
\hline & MR5 & 17.550 & 0.002 & 1.1275 & 0.0001 & 2.1327 & 0.0001 \\
\hline & MR6 & 17.678 & 0.002 & 1.1349 & 0.0001 & 2.1257 & 0.0002 \\
\hline & MR7 & 17.701 & 0.003 & 1.1364 & 0.0001 & 2.1246 & 0.0001 \\
\hline & MR8 & 17.463 & 0.001 & 1.1227 & 0.0001 & 2.1368 & 0.0002 \\
\hline & MR9 & 17.305 & 0.002 & 1.1137 & 0.0001 & 2.1476 & 0.0001 \\
\hline \multirow[t]{3}{*}{ Brake } & FSB-1 & 19.569 & 0.003 & 1.2200 & 0.0001 & 1.9598 & 0.0001 \\
\hline & FSB-2 & 20.199 & 0.002 & 1.2547 & 0.0001 & 1.9151 & 0.0001 \\
\hline & HBP-1 & 18.176 & 0.004 & 1.1651 & 0.0001 & 2.1052 & 0.0001 \\
\hline \multirow[t]{4}{*}{ Tire } & R30-1 & 17.937 & 0.003 & 1.1502 & 0.0001 & 2.1075 & 0.0002 \\
\hline & R43/54-1 & 18.190 & 0.002 & 1.1660 & 0.0001 & 2.0973 & 0.0001 \\
\hline & $\mathrm{R} 43 / 54-2$ & 18.181 & 0.002 & 1.1653 & 0.0001 & 2.0983 & 0.0001 \\
\hline & R56/57-1 & 18.138 & 0.002 & 1.1613 & 0.0001 & 2.0995 & 0.0002 \\
\hline \multirow[t]{4}{*}{ Manhole cover } & NKMHC-1 & 17.883 & 0.003 & 1.1450 & 0.0001 & 2.1262 & 0.0001 \\
\hline & NKMHC-2 & 17.547 & 0.004 & 1.1281 & 0.0001 & 2.1355 & 0.0002 \\
\hline & MRMHC-1 & 17.557 & 0.004 & 1.1284 & 0.0001 & 2.1332 & 0.0001 \\
\hline & MRMHC-2 & 17.550 & 0.002 & 1.1280 & 0.0001 & 2.1335 & 0.0002 \\
\hline \multirow[t]{6}{*}{ Road dust } & NKRD-1 & 17.438 & 0.002 & 1.1218 & 0.0001 & 2.1403 & 0.0001 \\
\hline & NKRD-2 & 17.762 & 0.001 & 1.1405 & 0.0001 & 2.1222 & 0.0002 \\
\hline & NKRD-3 & 17.728 & 0.002 & 1.1379 & 0.0001 & 2.1245 & 0.0001 \\
\hline & MRRD-1 & 17.890 & 0.003 & 1.1417 & 0.0001 & 2.1242 & 0.0001 \\
\hline & MRRD-2 & 17.777 & 0.002 & 1.1412 & 0.0001 & 2.1176 & 0.0002 \\
\hline & MRRD-3 & 17.347 & 0.002 & 1.1163 & 0.0001 & 2.1446 & 0.0001 \\
\hline \multirow[t]{4}{*}{ Road paint } & NKRP-1 & 17.930 & 0.002 & 1.1509 & 0.0001 & 2.0894 & 0.0001 \\
\hline & NKRP-2 & 18.301 & 0.002 & 1.1708 & 0.0001 & 2.0843 & 0.0001 \\
\hline & MRRP-1 & 17.866 & 0.001 & 1.1471 & 0.0001 & 2.1012 & 0.0001 \\
\hline & MRRP-2 & 18.135 & 0.001 & 1.1621 & 0.0001 & 2.0973 & 0.0002 \\
\hline Road tarmac & NKRS-1 & 18.148 & 0.001 & 1.1633 & 0.0001 & 2.0953 & 0.0001 \\
\hline surface & NKRS-2 & 18.252 & 0.001 & 1.1695 & 0.0001 & 2.0869 & 0.0001 \\
\hline
\end{tabular}


Isotopic signatures in atmospheric particulate matter suggest important contributions from recycled gasoline for lead and nonexhaust traffic sources for copper and zinc in aerosols in London, United Kingdom

\section{Highlights}

- Isotope ratios of $\mathrm{Cu}, \mathrm{Zn}$ and $\mathrm{Pb}$ were determined in $\mathrm{PM}_{10}$ collected at two road sites with contrasting traffic densities in central London, UK, and in potential sources.

- Despite the different traffic densities, no significant differences in the isotope signatures of $\mathrm{Cu}, \mathrm{Zn}$ and $\mathrm{Pb}$ are found in $\mathrm{PM}_{10}$, suggesting similar sources for each metal at both sites.

- Analysis of the isotopic composition of $\mathrm{Cu}, \mathrm{Zn}$ and $\mathrm{Pb}$ in $\mathrm{PM}_{10}$ and potential sources indicate important contributions from road dust resuspension, recycled leaded gasoline, tire and brake wear. 